\title{
Use of Modeling for the Prevention of Solids Formation during Canyon Processing of Legacy Nuclear Materials
}

\author{
William J. Crooks III and William D. Rhodes \\ Strategic Materials Technology Department \\ Savannah River Technology Center
}

Jerry D. Christian

Independent Consultant

February 2003 
This document was prepared in conjunction with work accomplished under Contract No. DE-AC09-96SR18500 with the U. S. Department of Energy.

\section{DISCLAIMER}

This report was prepared as an account of work sponsored by an agency of the United States Government. Neither the United States Government nor any agency thereof, nor any of their employees, makes any warranty, express or implied, or assumes any legal liability or responsibility for the accuracy, completeness, or usefulness of any information, apparatus, product or process disclosed, or represents that its use would not infringe privately owned rights. Reference herein to any specific commercial product, process or service by trade name, trademark, manufacturer, or otherwise does not necessarily constitute or imply its endorsement, recommendation, or favoring by the United States Government or any agency thereof. The views and opinions of authors expressed herein do not necessarily state or reflect those of the United States Government or any agency thereof.

This report has been reproduced directly from the best available copy.

Available for sale to the public, in paper, from: U.S. Department of Commerce, National Technical Information Service, 5285 Port Royal Road, Springfield, VA 22161, phone: (800) 553-6847, fax: (703) 605-6900

email: orders@ntis.fedworld.gov

online ordering: http://www.ntis.gov/help/index.asp

Available electronically at http://www.osti.gov/bridge

Available for a processing fee to U.S. Department of Energy and its contractors, in paper, from: U.S. Department of Energy, Office of Scientific and Technical Information, P.O. Box 62, Oak Ridge, TN 37831-0062,

phone: (865)576-8401,

fax: (865)576-5728

email: $\underline{\text { reports@ adonis.osti.gov }}$ 


\section{Table of Contents}

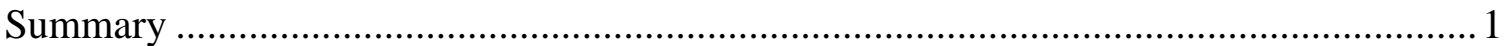

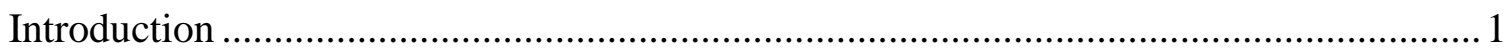

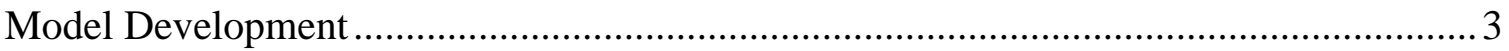

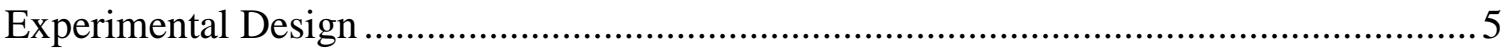

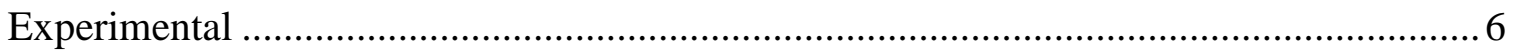

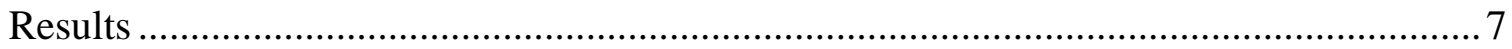

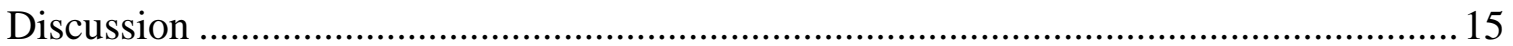

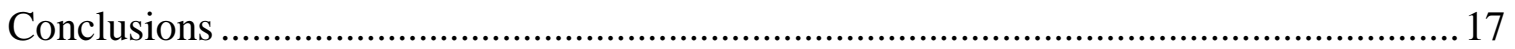

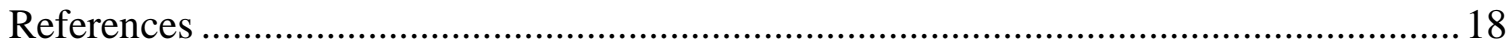




\section{List of Tables}

Table 1. Pitzer Multielectrolyte Eq. Parameters for Ternary Systems ........................... 8

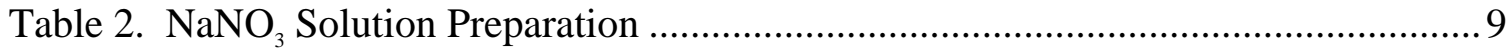

Table 3. $\mathrm{NaBF}_{4}$ Solution Preparation ….............................................................. 9

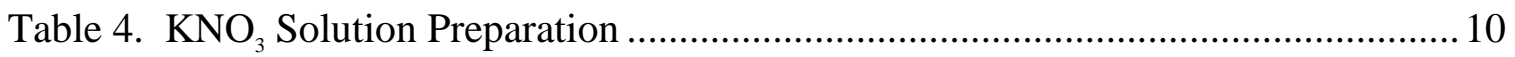

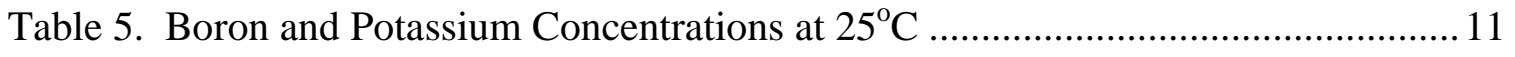

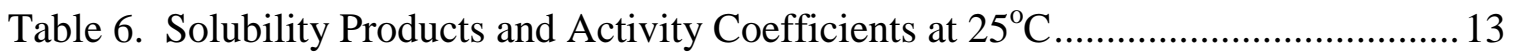

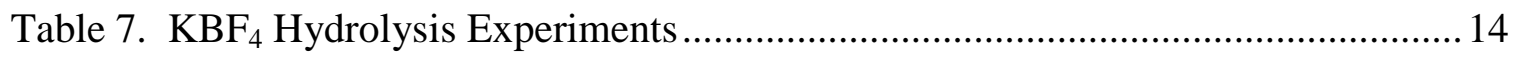

Table 8. $\mathrm{KBF}_{4}$ Solubility Data based on ICP Experimental Results, Molal Basis .......... 14

Table 9. Summary Comparisons at Ionic Strength of Saturation, No Added Salt ........... 14

Table 10. $\mathrm{KBF}_{4}$ Saturation Experiments in SRS Plant Solutions ................................ 17

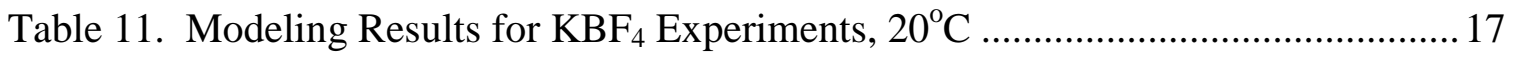

\section{List of Figures}

Figure 1. Pitzer Coefficients for $\mathrm{NaNO}_{3}$ Single Slat Equation.....................5

Figure 2. Solubility Product of $\mathrm{KBF}_{4}$ in Ionic Strength Adjuster Salts, $25^{\circ} \mathrm{C} \ldots \ldots \ldots . .12$

Figure 3. Activity Coefficient of $\mathrm{KBF}_{4}$ in Ionic Strength Adjuster Salts, $25^{\circ} \mathrm{C} \ldots \ldots . .12$

Figure 4. Pitzer-Kim Linear Eq. 9 Plot for $\mathrm{KBF}_{4}$ in $\mathrm{NaNO}_{3}$ ionic Strength Adjuster Showing Non-Linear Effect................................16 


\section{Use of Modeling for the Prevention of Solids Formation during Canyon Processing of Legacy Nuclear Materials}

\section{Summary}

The Department of Energy's (DOE) Environmental Management (EM) nuclear material stabilization program at the Savannah River Site (SRS) includes the dissolution and processing of legacy materials from various DOE sites. The SRS canyon facilities were designed to dissolve and process spent nuclear fuel and targets. As the processing of typical materials is completed, unusual and exotic nuclear materials are being targeted for stabilization. These unusual materials are often difficult to dissolve using historical flowsheet conditions and require more aggressive dissolver solutions. As such, solids must be prevented in the dissolver to avoid expensive delays associated with the build-up of insoluble material in downstream process equipment. Moreover, it is vital to prevent precipitation of all solids, especially plutonium-bearing solids and soluble neutron poisons, since their presence in dissolver solutions raises nuclear criticality safety issues. To prevent precipitation of undesirable solids in SRS aqueous process solutions, accurate computer models (incorporating plant specific fundamental data) are necessary.

Basic chemical data (solubility products and activity coefficients) applicable to the prevention of $\mathrm{KBF}_{4}$ precipitation, with key binary and ternary interaction parameters considered, were obtained. Increasing the ionic strength was found to increase the solubility of $\mathrm{KBF}_{4}$ substantially. This important observation suggests that plant solutions will be able to tolerate higher concentrations of boron than predicted without the incorporation of actual activity coefficients in model calculations. Incorporation of these data into the Idaho National Engineering and Environmental Laboratory (INEEL) speciation program, previously developed to calculate individual component concentrations in acidic aqueous fluoride systems will contribute to the application of the program (via the Pitzer correlation) to derive accurate SRS-specific activity coefficient parameters. Consequently, accurate predictions of solubilities of potentially precipitating species in plant solutions will be possible along with the ability to calculate solution adjustments to assure stability (prevent precipitation of unwanted species). The computer program will have potential applications at all DOE sites working with EM materials in aqueous solutions.

\section{Introduction}

To successfully model complex electrolyte systems, the following must be considered: 1) solution reactions and speciation, 2) reaction equilibrium constants, 3) activity coefficients of ionic, molecular, and solvent species, 4) reference states and properties at the reference state for ionic, salt, molecular, and solvent species, and 5) thermodynamic properties. ${ }^{1}$ The complexity of an electrolyte solution is due mainly to ionic speciation via dissociation, association, and salt precipitation reactions. The complex task of determining the extent a species exists under plant conditions involves solving a set of nonlinear equations for chemical equilibrium, and requires accurate reaction equilibrium constants and activities for all the species. The Pitzer ${ }^{2,3}$ or the 
electrolyte Non-Random Two Liquid (NRTL) model $^{4}$ may be applied to derive the activity coefficients. These are widely used models; parameters have been extensively tabulated for various salts and acids.

As a result of processing naval nuclear fuels at the Idaho Nuclear Technology and Engineering Center (INTEC), the Idaho National Engineering and Environmental Laboratory (INEEL) developed expertise in aqueous fluoride chemistry. This process included nuclear material dissolution in hydrofluoric and nitric acids and incorporated boron as a soluble neutron poison for criticality control. The need to keep boron and other species soluble required development of a thermodynamic speciation program, for predicting multiple fluoride species equilibrium concentrations in representative plant solutions. In recent years, the INEEL modeling capability has been expanded with the incorporation of complexation equilibrium calculations into a free energy minimization program with a database for over 15,000 compounds. To apply the INEEL model to a new application, the user must incorporate plant specific data for the performance of activity coefficient (via Pitzer model application) and phase equilibrium calculations. For application to multielectrolyte solutions, data for both single and binary salt solutions are required to obtain ion interaction parameters for all ions in solution.

Research and development pertaining to SRS canyon dissolver precipitation issues was important during the Sand, Slag, and Crucible (SS\&C) campaign of 1997. During the flowsheet development for this campaign, high concentrations of potassium fluoride in the boric acid-nitric acid dissolver solution resulted in white solids. These solids were identified as potassium tetrafluoroborate $\left(\mathrm{KBF}_{4}\right)$, indicating a decrease in soluble boron, a neutron adsorbing poison required for nuclear criticality control. The conditions that shift the equilibrium towards precipitation are qualitatively understood in terms of Le Chatelier's principle by considering the following equation:

$$
\mathrm{K}^{+}(\mathrm{aq})+\mathrm{H}_{3} \mathrm{BO}_{3}(\mathrm{aq})+4 \mathrm{~F}^{-}(\mathrm{aq})+3 \mathrm{H}^{+}(\mathrm{aq})=\mathrm{KBF}_{4}(\mathrm{~s})+3 \mathrm{H}_{2} \mathrm{O} \text { (l) (Eq. 1) }
$$

As a result of the SS\&C campaign issues, the INEEL model was used to predict nuclear material residue dissolution using calcium fluoride in the presence of boric acid and to predict the corrosion potential of the stainless steel dissolver vessel. ${ }^{5}$ However, the INEEL speciation program thermodynamic data are applicable at ionic strengths of INEEL process solutions; it did not possess activity coefficients applicable to SRS plant solutions. Therefore, application to SRS solutions with high ionic strength required that the INEEL model be improved with specific information on chemical species, such as activity coefficients and interaction parameters. Accordingly, the present study reports on the enhancement of the INEEL speciation computer program with new basic chemical data in order to better predict and avoid precipitation of undesirable solids in SRS aqueous process solutions. This incorporation will enable accurate predictions of solubilities of potentially precipitating species in plant solutions and provide the ability to calculate solution adjustments to assure stability. 


\section{Model Development}

For application of the INEEL (Pitzer) model to multielectrolyte solutions, data from both single salt and binary salt solutions are required to obtain ion-interaction parameters for all ions in solution. To this end, activity coefficients as a function of ionic strength were determined by $\mathrm{KBF}_{4}$ solubility measurements at various ionic strengths. Specifically, the determination of $\mathrm{KBF}_{4}$ binary and ternary activity coefficient parameters was based on $\mathrm{KBF}_{4}$ solubility measurements as a function of the ionic strength of an adjuster salt $\left(\mathrm{NaNO}_{3}, \mathrm{NaBF}_{4}\right.$, and $\left.\mathrm{KNO}_{3}\right)$. The fluoroborate ion $\left(\mathrm{BF}_{4}^{-}\right)$hydrolyzes slightly to yield $\mathrm{H}_{3} \mathrm{BO}_{3}$ and $\mathrm{HF}$. Therefore, chemical additions (small amounts of $\mathrm{HF}$ and $\mathrm{H}_{3} \mathrm{BO}_{3}$ at levels that did not contribute to ion interactions) were made to the test solutions, preventing hydrolysis of $\mathrm{BF}_{4}^{-}$that would otherwise occur to about $3.7 \% .^{6}$ These data, along with literature values of Pitzer parameters for interactions of $\mathrm{Na}^{+}-\mathrm{NO}_{3}^{-}$, $\mathrm{K}^{+}-\mathrm{NO}_{3}^{-}, \mathrm{Na}^{+}-\mathrm{BF}_{4}^{-}$, and $\mathrm{K}^{+}-\mathrm{Na}^{+}$enabled evaluation of all pertinent two-salt interaction parameters yielding $\mathrm{KBF}_{4}$ activity coefficients as a function of ionic strength.

The following description is developed in terms of individual ions of a salt being characterized, rather than simple solubility of the pure salt, so that solubility product can be expressed when the salt is in the presence of an ionic strength adjuster with a common ion. Once the salt solubilities have been determined as a function of ionic strength, the activity coefficients are calculated as follows. For the general salt dissolution, Eq. (2), the molal concentration equilibrium constant (solubility product, $\mathrm{K}_{\mathrm{m}}$ ) and thermodynamic equilibrium constant, $\mathrm{K}_{\mathrm{Th}}$, are obtained by Eqs. (3) and (4).

$$
\begin{gathered}
\mathrm{A}_{\mathrm{x}} \mathrm{B}_{\mathrm{y}}=\mathrm{xA}^{\mathrm{z+}}+\mathrm{yB}^{\mathrm{z}-} \\
\mathrm{K}_{\mathrm{m}}=\mathrm{m}_{\mathrm{A}^{\mathrm{z}}}^{\mathrm{x}} \mathrm{m}_{\mathrm{B}^{\mathrm{z}-}}^{\mathrm{y}} \\
\mathrm{K}_{\mathrm{Th}}=\mathrm{a}_{\mathrm{A}^{\mathrm{z}+}}^{\mathrm{x}} \mathrm{a}_{\mathrm{B}^{\mathrm{z}-}}^{\mathrm{y}}=\mathrm{K}_{\mathrm{m}} \gamma_{ \pm}^{v}
\end{gathered}
$$

where, $\mathrm{m}$ is the molal concentration, $\mathrm{a}$ is the activity, $\gamma_{ \pm}$is the mean molal activity coefficient $\left[\left(\gamma_{\mathrm{A}_{z+}}^{\mathrm{x}} \gamma_{\mathrm{B}_{z^{-}}}^{\mathrm{y}}\right)^{1 / v}\right]$, and $v$ is $\mathrm{x}+\mathrm{y}$. Let $\mathrm{K}_{\mathrm{m}, 0}$ and $\gamma_{0}$ be initially the solubility product (molal) and the mean activity coefficient, respectively, of the salt in pure water and $\mathrm{K}_{\mathrm{m}}$ and $\gamma_{ \pm}$be the corresponding values in a solution with added electrolyte that increases the ionic strength, $\mathrm{I}\left[\mathrm{I}=1 / 2 \sum_{\mathrm{i}} \mathrm{m}_{\mathrm{i}} \mathrm{z}_{\mathrm{i}}^{2}\right.$, in the present case, $\mathrm{I}=$ $\left.1 / 2\left(m_{A_{z+}} z_{+}^{2}+m_{B_{z-}} z_{-}^{2}\right)\right]$. Then,

$$
\mathrm{K}_{\mathrm{Th}}=\mathrm{K}_{\mathrm{m}, 0} \gamma_{0}^{v}=\mathrm{K}_{\mathrm{m}} \gamma_{ \pm}^{v}
$$

so that $\mathrm{K}_{\mathrm{m}} \gamma_{ \pm}^{v}=\mathrm{K}_{\mathrm{m}, 0} \gamma_{0}^{v}$. Taking logarithms, we have

$$
\log \mathrm{K}_{\mathrm{m}}=\log \left(\mathrm{K}_{\mathrm{m}, 0} \gamma_{0}^{\mathrm{v}}\right)-\log \gamma_{ \pm}^{v}
$$


Once $\mathrm{K}_{\mathrm{m}, 0} \gamma_{0}^{v}$ is known, the activity coefficient at a given ionic strength can be calculated from the measured solubility product. To obtain $\mathrm{K}_{\mathrm{m}, 0} \gamma_{0}^{v}, \log \mathrm{K}_{\mathrm{m}}$ is plotted against $\mathrm{I}^{1 / 2}$. The plot is extrapolated to $\mathrm{I}^{1 / 2}=0$. The intercept gives $\mathrm{K}_{\mathrm{m}, 0} \gamma_{0}^{v}$ at zero ionic strength, where $\gamma_{0}=1$. Then, from the measured solubility product at each ionic strength, Eq. (5) is solved for $\gamma_{ \pm}$.

$$
\gamma_{ \pm}=\left(\frac{K_{m, 0} \gamma_{0}^{v}}{K_{m}}\right)^{1 / v}
$$

The form of the suggested extrapolation equation arises from the limiting Debye-Hückel law, which predicts a linear relation between $\log \gamma_{ \pm}$and $\mathrm{I}^{1 / 2}$ at very low ionic strengths. This method is valid only up to a few hundredths molal and was not used.

A better extrapolation plot was applied herein ${ }^{7}$ and used an extended DebyeHückel equation developed by Davies ${ }^{8}$ :

$$
\log K_{m}-\frac{A_{\gamma} \Delta z^{2} I^{1 / 2}}{1+I^{1 / 2}}=\log K_{m, 0}+b I
$$

where $\mathrm{A}_{\gamma}$, the Debye-Hückel limiting slope, is 0.511 at $25^{\circ} \mathrm{C}$ and $\Delta \mathrm{z}^{2}$ is $\Sigma\left(z_{\text {products }}\right)^{2}-\left(z_{\text {reactants }}\right)^{2}$. The left side was plotted against I and extrapolated to zero I, yielding $\log \mathrm{K}_{\mathrm{m}, 0}$ at the intercept. The $\mathrm{K}_{\mathrm{m}, 0}$ value was determined from the lower ionic strength data, and activity coefficients at all ionic strengths were evaluated from Eq. (7) with $\gamma_{0}=1$. Although, Phillips et al. applied this function to evaluate solubility products at zero ionic strength from data up to 3 molal ionic strength, ${ }^{7}$ the function was originally developed by fitting data below about 0.15 molal. ${ }^{8}$ Thus, precise data exhibits curvature above 0.25 molal, evidenced by results obtained herein for $\mathrm{KBF}_{4}$ in sodium nitrate $\left(\mathrm{NaNO}_{3}\right)$. Consequently, only data up to 0.25 molal ionic strength were used for the linear extrapolation to zero ionic strength.

An initial assessment of the Pitzer model was performed based on literature data and calculating individual activity coefficients at experimental conditions. This demonstrated that, when fitting the data up to 6 molal, the Pitzer model calculated the activity coefficients with an accuracy of $0.3 \%$. For data above 6-molal, the effect on the fitting accuracy of the overall data must be considered on a case-by-case basis. Figure 1 shows the prediction capability of Pitzer single-salt equation parameters for $\mathrm{NaNO}_{3}$ activity coefficients. ${ }^{9}$

Upon determination of individual species activity coefficients, plant solution stability is provided via application of the HSC program, a commercial free energy minimization program (HSC Chemistry ${ }^{\circledR}$ for Windows). ${ }^{10}$ The INEEL model possesses general equations and methodology to convert equilibrium constants into a consistent set of thermodynamic parameters for use in the HSC program. As a result, solution compositions can be varied to determine concentration limits where precipitation occurs. 
Figure 1. Pitzer Coefficients for $\mathrm{NaNO}_{3}$ Single Salt Equation.

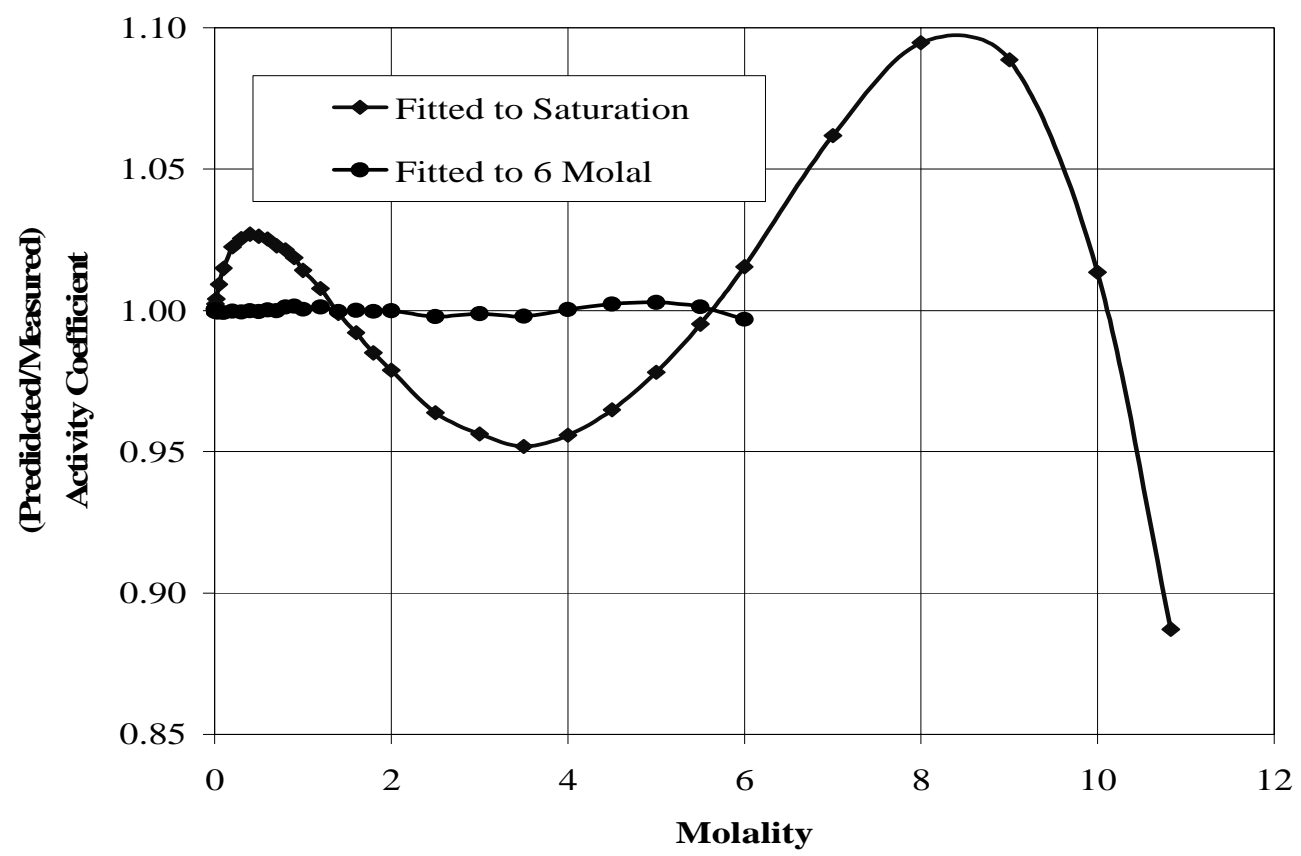

\section{Experimental Design}

The experimental design to determine critical ion interaction parameters for ion pairs is shown in Table 1. For the $\mathrm{KBF}_{4}-\mathrm{NaNO}_{3}$ system (no common ion), the $\theta$ and $\psi$ parameters were obtained from the $\mathrm{KBF}_{4}-\mathrm{NaBF}_{4}$ and $\mathrm{KBF}_{4}-\mathrm{KNO}_{3}$ systems. Then, the $\mathrm{K}^{+}-\mathrm{BF}_{4}^{-}$parameters of $\beta^{(0)}, \beta^{(1)}$, and $\mathrm{C}^{\varphi}$ to high ionic strength were obtained with this system. For the $\mathrm{KBF}_{4}-\mathrm{NaBF}_{4}$ system (common anion), $\psi$ was assumed for $\mathrm{K}^{+}-\mathrm{Na}^{+}-\mathrm{BF}_{4}^{-}=-0.002$, similar to that for $\mathrm{K}^{+}-\mathrm{Na}^{+}-\mathrm{Cl}^{-}, \mathrm{K}^{+}-\mathrm{Na}^{+}-\mathrm{Br}^{-}$, and $\mathrm{K}^{+}-\mathrm{Na}^{+}-\mathrm{NO}_{3}^{-} . \mathrm{K}^{+}$solubility concentration was measured as function of $\mathrm{NaBF}_{4}$ added concentration. $\left[\mathrm{KBF}_{4}\right]$ varies dramatically with $\left[\mathrm{NaBF}_{4}\right]$, so its parameters are easily attainable. Data up to 0.2 to $0.4 \mathrm{~m} \mathrm{NaBF}_{4}$ is reasonable, at which $\left[\mathrm{KBF}_{4}\right]$ was expected to have decreased to about $0.0088 \mathrm{~m}$ and $\left[\mathrm{K}^{+}\right] /\left[\mathrm{BF}_{4}^{-}\right]$to 0.042 . (In practice, data up to 2.5 $\mathrm{m} \mathrm{KBF}_{4}$ was obtained, as the solubility increased as a result of activity coefficients being greater than unity.) This system has the advantage over the $\mathrm{KBF}_{4}-\mathrm{KNO}_{3}$ system in that the interaction parameter for $\mathrm{K}^{+}-\mathrm{Na}^{+}$is known, whereas for $\mathrm{BF}_{4}^{-}-\mathrm{NO}_{3}^{-}$it is not. This system was used to get the $\mathrm{K}^{+}-\mathrm{BF}_{4}^{-}$parameters. Then, the $\mathrm{KBF}_{4}-\mathrm{KNO}_{3}$ system, was used to get the $\mathrm{BF}_{4}^{-}-\mathrm{NO}_{3}^{-} \theta$ parameter. These two systems were also used to determine the $\psi$ parameters. The limitation of this system, and the next, is that the $\mathrm{KBF}_{4}$ activity coefficient will not be obtained at high ionic strength. Therefore, the $\mathrm{KBF}_{4}-\mathrm{NaNO}_{3}$ system was applied to extend the $\mathrm{K}^{+}-\mathrm{BF}_{4}^{-}$parameter determinations to high ionic strength. For the $\mathrm{KBF}_{4}-\mathrm{KNO}_{3}$ system, $\mathrm{BF}_{4}^{-}$solubility concentration was measured as function of $\mathrm{KNO}_{3}$ concentration. $\left[\mathrm{KBF}_{4}\right]$ varies dramatically with $\left[\mathrm{KNO}_{3}\right]$, so parameter attainment was straightforward. Data was expected to be obtained up to 0.2 to $0.4 \mathrm{~m}$ 
$\mathrm{KNO}_{3}$, where $\left[\mathrm{KBF}_{4}\right]$ was anticipated to have decreased to about $0.0088 \mathrm{~m}$ and $\left[\mathrm{K}^{+}\right] /\left[\mathrm{BF}_{4}^{-}\right]$to 0.042 . Again, increased solubilities countering the common ion effect enabled data collection to $2.5 \mathrm{~m} \mathrm{KNO}_{3}$.

\section{Experimental}

The solubility of $\mathrm{KBF}_{4}$ was determined as a function of ionic strength in three matrixes: $\mathrm{NaNO}_{3}, \mathrm{KNO}_{3}$, and $\mathrm{NaBF}_{4}$. To this end, a series of electrolyte solutions $\left(\mathrm{NaNO}_{3}, \mathrm{NaBF}_{4}\right.$, and $\left.\mathrm{KNO}_{3}\right)$ was prepared as illustrated in Tables 2, 3, and 4. From each original solution, three additional solutions were prepared with successively increasing spikes of $\mathrm{KBF}_{4}$. These solutions were analyzed for boron and potassium by ICP-ES. Consequently, each original solution was represented by a three-point graph of both boron and potassium concentrations. These graphs were extrapolated back to zero spike addition to ascertain boron and potassium concentrations of the original solution. This multiple successive standard spike addition method was applied to calibrate the ICP in the experimental matrix by removing all effects except changing the $\mathrm{BF}_{4}^{-}$concentration.

The solubility measurements were performed at $25.0 \pm 0.5^{\circ} \mathrm{C}$. These solutions were allowed to equilibrate (mild agitation) at $25 \pm 0.5^{\circ} \mathrm{C}$ for 14 days prior to sample initiation. The concentrations of $\mathrm{B}$ and $\mathrm{K}$ were determined (ICP-ES) from three series of dilutions. Materials used were $\mathrm{KBF}_{4}$ (Aldrich, anhydrous, 99.95+\%), $\mathrm{H}_{3} \mathrm{BO}_{3}$ (Aldrich, 99.5\%), HF (Optima, 49\%), and purified Millipore water (to $17 \mathrm{M} \mathrm{ohm}$ ). Samples were obtained with syringe filters, $25 \mathrm{~mm}$ GD/X disposable, 25-mm diameter, 0.2micrometer pore size (Whatman, Inc.) The experimental apparatus (constant temperature shaker water bath) provided accurate temperature control and efficient sampling for solubility determinations. The $\mathrm{KBF}_{4}$ solutions were analyzed for $\mathrm{B}$ and $\mathrm{K}$ concentration by inductively couple plasma-atomic emission spectroscopy (ICP-ES). The solubility at zero ionic strength was determined by a Phillips linear plot (Eqn. 8) of data up to 0.3 molal ionic strength. From this value, the activity coefficient of $\mathrm{KBF}_{4}$ was determined from solubility measured at each ionic strength. These data are required input to the activity coefficient model to determine the Pitzer parameters.

Quantitative evaluations were made of chemical adjustments to make to the $\mathrm{KBF}_{4}$ test solutions to prevent hydrolysis of $\mathrm{BF}_{4}^{-}$to less than $1 \%$ that would otherwise occur to about 3.7\%; this involved small additions of $\mathrm{HF}$ and $\mathrm{H}_{3} \mathrm{BO}_{3}$ at levels that did not contribute to ion interactions. The $\mathrm{KBF}_{4}$ solubility measurements for activity coefficient determinations were made in one set of experiments using $\mathrm{NaNO}_{3}$ as an ionic strength adjuster. Interpretation of the data was based on the assumption that $\mathrm{Na}^{+}$and $\mathrm{BF}_{4}^{-}$ions do not interact to form a complex in solution, which would cause the solubility of $\mathrm{KBF}_{4}$ to increase. Literature information supports this assumption, i.e., no mention is found of the existence of a complexation between the ions.

A special set of tests was also conducted that investigated $\mathrm{KBF}_{4}$ hydrolysis. Specifically, the hydrolysis of $\mathrm{KBF}_{4}$ was determined in a pure $\mathrm{KBF}_{4}$ aqueous solution, a second solution with the same concentration of $\mathrm{H}_{3} \mathrm{BO}_{3}$ and $\mathrm{HF}$ as in the above tests, and a 
final solution with an excess of these constituents. These solutions were also held to 25.0 $\pm 0.5^{\circ} \mathrm{C}$. Table 7 provides the solution make-up concentrations.

\section{Results}

Characterizations of the three electrolyte solutions, $\mathrm{NaNO}_{3}, \mathrm{NaBF}_{4}$, and $\mathrm{KNO}_{3}$, are provided in Tables 2, 3, and 4 respectively. The equilibrium $\mathrm{BF}_{4}^{-}$and $\mathrm{K}^{+}$ concentrations along with $\mathrm{BF}_{4}^{-}$hydrolysis are shown in Table 5 and Figures 2 and 3. The small residual hydrolysis was calculated and subtracted from the intial $\mathrm{BF}_{4}^{-}$concentration to obtain the equilibrium concentration using the INEEL speciation program, which included thermodynamic data ${ }^{11}$ for evaluating the equilibrium constant $\left(6.41 \times 10^{-12}\right.$ at $25^{\circ} \mathrm{C}$ ) for the hydrolysis reaction

$$
\mathrm{BF}_{4}^{-}(\mathrm{aq})+3 \mathrm{H}_{2} \mathrm{O}=3 \mathrm{HF}(\mathrm{aq})+\mathrm{F}^{-}(\mathrm{aq})+\mathrm{H}_{3} \mathrm{BO}_{3}(\mathrm{aq})
$$

(compared to the value of $1.0 \times 10^{-11}$ of Ryss and Donskaya ${ }^{12}$ ). In the $\mathrm{NaNO}_{3}$ system, the boron and potassium concentrations were independently measured using ICP-ES. In the $\mathrm{NaBF}_{4}$ system, the potassium was directly measured and the $\mathrm{BF}_{4}^{-}$(before hydrolysis) was calculated as the sum of the accurately measured (by weight) $\mathrm{NaBF}_{4}$ concentration and the potassium concentration. In the $\mathrm{KNO}_{3}$ system, the boron was directly measured and the $\mathrm{K}^{+}$was calculated as the sum of the accurately measured (by weight) $\mathrm{KNO}_{3}$ and the $\mathrm{BF}_{4}^{-}$(before hydrolysis).

The resultant solubility products and activity coefficients are shown in Table 6. Table 7 shows the results of the gravimetric hydrolysis experiments. Table 8 illustrates the $\mathrm{KBF}_{4}$ solubility data, based on ICP experimental results, on a molal basis at $25^{\circ} \mathrm{C}$. It should be noted that the literature data are assumed to be at the ionic strength of saturation - there is no discernment of data as a function of ionic strength with an extrapolation to zero ionic strength. Finally, Table 9 provides a summary comparison of the solubility data at ionic strength of saturation, no added salt, $25^{\circ} \mathrm{C}$. The activity coefficients were calculated with the use of the ICP data (scatter of 5 to10\%) in combination with the $\mathrm{K}_{\mathrm{SP}}$ extrapolated (Davies equation) to zero ionic strength, $\mathrm{K}_{\mathrm{SP}}^{0}=$ 0.00267 , which corresponds to the $K_{\mathrm{SP}}$ value at saturation, no added salt, of 0.00368 . 
Table 1.

Pitzer Multielectrolyte Eq. Parameters for Ternary Systems (Two Salts + Water)

$\sqrt{ }=$ parameter known from literature

$-=$ not applicable

$\mathrm{x}=$ parameter needed

$\mathrm{KBF}_{4}-\mathrm{NaNO}_{3}$ System (No Common Ion)

\begin{tabular}{|c|c|c|c|c|c|}
\hline \multirow{2}{*}{ Interacting Ions } & \multicolumn{3}{|c|}{ Single Salt Parameters } & \multicolumn{2}{c|}{ Two-Salt Parameters } \\
\cline { 2 - 6 } & $\beta^{(0)}$ & $\beta^{(1)}$ & $\mathrm{C}^{\varphi}$ & $\theta$ & - \\
\hline $\mathrm{Na}^{+}-\mathrm{NO}_{3}^{-}$ & $\sqrt{ }$ & $\sqrt{ }$ & $\sqrt{ }$ & - & - \\
\hline $\mathrm{K}^{+}-\mathrm{NO}_{3}^{-}$ & $\sqrt{ }$ & $\sqrt{ }$ & $\sqrt{ }$ & - & - \\
\hline $\mathrm{Na}^{+}-\mathrm{BF}_{4}^{-}$ & $\sqrt{y}$ & $\mathrm{x}$ & $\mathrm{x}$ & - & - \\
\hline $\mathrm{K}^{+}-\mathrm{BF}_{4}^{-}$ & - & - & - & $\sqrt{ }$ & - \\
\hline $\mathrm{K}^{+}-\mathrm{Na}^{+}$ & - & - & - & $\mathrm{x}$ & - \\
\hline $\mathrm{BF}_{4}^{-}-\mathrm{NO}_{3}^{-}$ & - & - & - & - & $\mathrm{x}$ \\
\hline $\mathrm{BF}_{4}^{-}-\mathrm{NO}_{3}^{-}-\mathrm{K}^{+}$ & - & - & - & - & $\mathrm{x}$ \\
\hline $\mathrm{BF}_{4}^{-}-\mathrm{NO}_{3}^{-}-\mathrm{Na}^{+}$ & - & - & - & - & $\sqrt{ }$ \\
\hline $\mathrm{K}^{+}-\mathrm{Na}^{+}-\mathrm{NO}_{3}^{-}$ & - & - & - & - & $\mathrm{x}$ \\
\hline $\mathrm{K}^{+}-\mathrm{Na}^{+}-\mathrm{BF}_{4}^{-}$ & - & & & & - \\
\hline
\end{tabular}

$\mathrm{KBF}_{4}-\mathrm{NaBF}_{4}$ System (Common Anion)

\begin{tabular}{|c|c|c|c|c|c|}
\hline \multirow{2}{*}{ Interacting Ions } & \multicolumn{3}{|c|}{ Single Salt Parameters } & \multicolumn{2}{c|}{ Two-Salt Parameters } \\
\cline { 2 - 6 } & $\beta^{(0)}$ & $\beta^{(1)}$ & $\mathrm{C}^{\varphi}$ & $\theta$ & $\psi$ \\
\hline $\mathrm{Na}^{+}-\mathrm{BF}_{4}^{-}$ & $\sqrt{ }$ & $\sqrt{ }$ & $\sqrt{ }$ & - & - \\
\hline $\mathrm{K}^{+}-\mathrm{BF}_{4}^{-}$ & $\mathrm{x}$ & $\mathrm{x}$ & $\mathrm{x}$ & $\sqrt{ }$ & - \\
\hline $\mathrm{K}^{+}-\mathrm{Na}^{+}$ & - & - & - & - & $\mathrm{x}$ \\
\hline $\mathrm{K}^{+}-\mathrm{Na}^{+}-\mathrm{BF}_{4}^{-}$ & - & - & - & - \\
\hline
\end{tabular}

$\mathrm{KBF}_{4}-\mathrm{KNO}_{3} \mathrm{System}_{\text {(Common Cation) }}$

\begin{tabular}{|c|c|c|c|c|c|}
\hline \multirow{2}{*}{ Interacting Ions } & \multicolumn{3}{|c|}{ Single Salt Parameters } & \multicolumn{2}{c|}{ Two-Salt Parameters } \\
\hline $\mathrm{K}^{+}-\mathrm{NO}_{3}^{-}$ & $\beta^{(0)}$ & $\beta^{(1)}$ & $\mathrm{C}^{\varphi}$ & $\theta$ & $\psi$ \\
\hline $\mathrm{K}^{+}-\mathrm{BF}_{4}^{-}$ & $\mathrm{x}$ & $\sqrt{ }$ & $\sqrt{ }$ & - & - \\
\hline $\mathrm{K}^{+}-\mathrm{Na}^{+}$ & - & $\mathrm{x}$ & $\mathrm{x}$ & - & - \\
\hline $\mathrm{BF}_{4}^{-}-\mathrm{NO}_{3}^{-}$ & - & - & - & $\sqrt{ }$ & - \\
\hline $\mathrm{BF}_{4}^{-}-\mathrm{NO}_{3}^{-}-\mathrm{K}^{+}$ & - & - & - & $\mathrm{x}$ & - \\
\hline
\end{tabular}


Table 2.

$\underline{\mathrm{NaNO}}_{3}$ Solution Preparation

\begin{tabular}{|c|c|c|c|c|c|c|c|c|c|c|c|}
\hline \multirow{3}{*}{$\begin{array}{c}\begin{array}{c}\mathrm{NaNO}_{3} \\
\text { target } \\
\text { molality }\end{array} \\
\frac{\mathrm{m}}{}\end{array}$} & \multirow{3}{*}{$\begin{array}{c}\text { Density } \\
\mathrm{g} / \mathrm{mL}\end{array}$} & \multicolumn{4}{|c|}{ Material Used for Solution } & \multicolumn{6}{|c|}{ Solution Characterization } \\
\hline & & \multirow{2}{*}{$\begin{array}{l}\text { Water } \\
\text { gram }\end{array}$} & \multirow{2}{*}{$\begin{array}{c}\mathrm{H}_{3} \mathrm{BO}_{3} \\
\text { grams }\end{array}$} & \multirow{2}{*}{$\begin{array}{c}\mathrm{HF} \\
25 \mathrm{M} \\
\mu \text { liters }\end{array}$} & \multirow{2}{*}{$\begin{array}{c}\mathrm{NaNO}_{3} \\
\text { grams }\end{array}$} & \multicolumn{2}{|c|}{$\mathrm{NaNO}_{3}$} & \multicolumn{2}{|c|}{$\mathrm{HF}$} & \multicolumn{2}{|c|}{$\mathrm{H}_{3} \mathrm{BO}_{3}$} \\
\hline & & & & & & $\mathrm{M}$ & molality & $\mathrm{M}$ & molality & $\mathrm{M}$ & molality \\
\hline 0.00 & 1.001 & 100.175 & 0.0161 & 21 & 0 & 0 & 0 & 0.00510 & 0.00513 & 0.00258 & 0.00260 \\
\hline 0.05 & 1.004 & 100.288 & 0.0164 & 21 & 0.429 & 0.0499 & 0.0503 & 0.00508 & 0.00513 & 0.00262 & 0.00265 \\
\hline 0.10 & 1.007 & 100.298 & 0.0166 & 21 & 0.855 & 0.0993 & 0.100 & 0.00508 & 0.00513 & 0.00265 & 0.00268 \\
\hline 0.20 & 1.013 & 100.354 & 0.0165 & 21 & 1.712 & 0.198 & 0.201 & 0.00506 & 0.00512 & 0.00263 & 0.00266 \\
\hline 0.50 & 1.030 & 100.346 & 0.0159 & 21 & 4.244 & 0.486 & 0.498 & 0.00501 & 0.00512 & 0.00251 & 0.00256 \\
\hline 1.00 & 1.056 & 100.399 & 0.0167 & 21 & 8.502 & 0.959 & 0.996 & 0.00493 & 0.00512 & 0.00259 & 0.00269 \\
\hline 1.50 & 1.082 & 100.169 & 0.0160 & 21 & 12.766 & 1.421 & 1.500 & 0.00486 & 0.00513 & 0.00245 & 0.00259 \\
\hline 2.00 & 1.106 & 100.330 & 0.0165 & 21 & 17.158 & 1.876 & 2.012 & 0.00478 & 0.00513 & 0.00248 & 0.00266 \\
\hline 2.50 & 1.129 & 100.245 & 0.0165 & 21 & 21.414 & 2.305 & 2.513 & 0.00470 & 0.00513 & 0.00244 & 0.00266 \\
\hline 3.00 & 1.151 & 100.119 & 0.0160 & 21 & 25.656 & 2.721 & 3.015 & 0.00464 & 0.00514 & 0.00233 & 0.00259 \\
\hline 3.50 & 1.172 & 100.176 & 0.0164 & 21 & 29.960 & 3.125 & 3.519 & 0.00456 & 0.00513 & 0.00235 & 0.00265 \\
\hline 4.00 & 1.192 & 100.212 & 0.0167 & 21 & 34.120 & 3.501 & 4.006 & 0.00448 & 0.00513 & 0.00236 & 0.00270 \\
\hline 5.00 & 1.227 & 100.686 & 0.0167 & 21 & 42.519 & 4.207 & 4.968 & 0.00432 & 0.00511 & 0.00227 & 0.00268 \\
\hline 6.00 & 1.264 & 100.552 & 0.0167 & 21 & 51.097 & 4.912 & 5.979 & 0.00420 & 0.00511 & 0.00221 & 0.00269 \\
\hline 7.00 & 1.300 & 100.168 & 0.0167 & 21 & 60.182 & 5.621 & 7.069 & 0.00408 & 0.00513 & 0.00215 & 0.00270 \\
\hline 8.00 & 1.329 & 100.294 & 0.0167 & 21 & 68.791 & 6.232 & 8.070 & 0.00396 & 0.00513 & 0.00208 & 0.00269 \\
\hline 9.00 & 1.354 & 100.282 & 0.0164 & 21 & 76.969 & 6.785 & 9.030 & 0.00385 & 0.00513 & 0.00199 & 0.00265 \\
\hline
\end{tabular}

Table 3.

$\underline{\mathrm{NaBF}}_{4}$ Solution Preparation

\begin{tabular}{|c|c|c|c|c|c|c|c|c|c|c|c|}
\hline \multirow{3}{*}{$\begin{array}{c}\begin{array}{c}\mathrm{NaBF}_{4} \\
\text { target } \\
\text { molality }\end{array} \\
\mathrm{m}\end{array}$} & \multirow{3}{*}{$\begin{array}{c}\text { Density } \\
\mathrm{g} / \mathrm{mL}\end{array}$} & \multicolumn{4}{|c|}{ Material Used for Solution } & \multicolumn{6}{|c|}{ Solution Characterization } \\
\hline & & \multirow{2}{*}{$\begin{array}{l}\text { Water } \\
\text { gram }\end{array}$} & \multirow{2}{*}{$\begin{array}{c}\mathrm{H}_{3} \mathrm{BO}_{3} \\
\text { grams }\end{array}$} & \multirow{2}{*}{$\begin{array}{c}\mathrm{HF} \\
25 \mathrm{M} \\
\mu \text { liters }\end{array}$} & \multirow{2}{*}{$\begin{array}{c}\mathrm{NaNO}_{3} \\
\text { grams }\end{array}$} & \multicolumn{2}{|c|}{$\mathrm{NaBF}_{4}$} & \multicolumn{2}{|c|}{$\mathrm{HF}$} & \multicolumn{2}{|c|}{$\mathrm{H}_{3} \mathrm{BO}_{3}$} \\
\hline & & & & & & $\mathrm{M}$ & molality & $\mathrm{M}$ & molality & $\mathrm{M}$ & molality \\
\hline 0 & 1.001 & 100.248 & 0.0164 & 22 & 0 & 0.000 & 0 & 0.00509 & 0.00513 & 0.00258 & 0.00260 \\
\hline 0.05 & 1.003 & 100.280 & 0.0141 & 18 & 0.5509 & 0.050 & 0.050 & 0.00448 & 0.00451 & 0.00226 & 0.00228 \\
\hline 0.10 & 1.006 & 100.191 & 0.0112 & 14 & 1.1001 & 0.099 & 0.100 & 0.00347 & 0.00350 & 0.00179 & 0.00181 \\
\hline 0.20 & 1.012 & 100.307 & 0.0042 & 5.4 & 2.1946 & 0.197 & 0.199 & 0.00133 & 0.00135 & 0.00067 & 0.00068 \\
\hline 0.30 & 1.018 & 100.169 & 0 & 0 & 3.2357 & 0.290 & 0.294 & 0 & 0 & 0 & 0 \\
\hline 0.40 & 1.024 & 100.124 & 0 & 0 & 4.4135 & 0.393 & 0.402 & 0 & 0 & 0 & 0 \\
\hline 0.50 & 1.031 & 100.279 & 0 & 0 & 5.4934 & 0.487 & 0.499 & 0 & 0 & 0 & 0 \\
\hline 1.00 & 1.062 & 100.227 & 0 & 0 & 11.0396 & 0.959 & 1.003 & 0 & 0 & 0 & 0 \\
\hline 1.50 & 1.091 & 100.280 & 0 & 0 & 16.4896 & 1.402 & 1.498 & 0 & 0 & 0 & 0 \\
\hline 2.00 & 1.120 & 100.307 & 0 & 0 & 22.0672 & 1.837 & 2.004 & 0 & 0 & 0 & 0 \\
\hline 2.50 & 1.147 & 100.341 & 0 & 0 & 27.6421 & 2.253 & 2.509 & 0 & 0 & 0 & 0 \\
\hline
\end{tabular}


Table 4.

$\underline{\mathrm{KNO}}_{3}$ Solution Preparation

\begin{tabular}{|c|c|c|c|c|c|c|c|c|c|c|c|}
\hline \multirow{3}{*}{$\begin{array}{c}\begin{array}{c}\mathrm{KNO}_{3} \\
\text { target } \\
\text { molality }\end{array} \\
\mathrm{m}\end{array}$} & \multirow{3}{*}{$\begin{array}{l}\text { Density } \\
\mathrm{g} / \mathrm{mL}\end{array}$} & \multicolumn{4}{|c|}{ Material Used for Solution } & \multirow{2}{*}{\multicolumn{2}{|c|}{$\mathrm{KNO}_{3}$}} & \multirow{2}{*}{\multicolumn{2}{|c|}{$\mathrm{HF}$}} & \multirow{2}{*}{\multicolumn{2}{|c|}{$\mathrm{H}_{3} \mathrm{BO}_{3}$}} \\
\hline & & \multirow{2}{*}{$\begin{array}{l}\text { Water } \\
\text { gram } \\
\end{array}$} & \multirow{2}{*}{$\begin{array}{c}\mathrm{H}_{3} \mathrm{BO}_{3} \\
\text { grams }\end{array}$} & \multirow{2}{*}{$\begin{array}{c}\mathrm{HF} \\
25 \mathrm{M} \\
\mu \text { liters }\end{array}$} & \multirow{2}{*}{$\begin{array}{l}\mathrm{KNO}_{3} \\
\text { grams }\end{array}$} & & & & & & \\
\hline & & & & & & $\mathrm{M}$ & molality & $\mathrm{M}$ & molality & $\mathrm{M}$ & molality \\
\hline 0.00 & 1.0012 & 100.405 & 0.0163 & 21 & 0.0000 & 0 & 0 & 0.0051 & 0.0051 & 0.0026 & 0.0026 \\
\hline 0.05 & 1.0030 & 100.511 & 0.0177 & 22 & 0.4980 & 0.0486 & 0.0490 & 0.0054 & 0.0055 & 0.0028 & 0.0029 \\
\hline 0.10 & 1.0061 & 100.195 & 0.0179 & 23 & 1.0773 & 0.1053 & 0.1064 & 0.0056 & 0.0057 & 0.0029 & 0.0029 \\
\hline 0.20 & 1.0117 & 100.282 & 0.0195 & 25 & 2.0921 & 0.2037 & 0.2063 & 0.0060 & 0.0061 & 0.0031 & 0.0031 \\
\hline 0.30 & 1.0171 & 100.301 & 0.0189 & 24 & 3.0613 & 0.2969 & 0.3019 & 0.0058 & 0.0059 & 0.0030 & 0.0030 \\
\hline 0.40 & 1.0230 & 100.288 & 0.0192 & 25 & 4.0677 & 0.3929 & 0.4012 & 0.0060 & 0.0061 & 0.0030 & 0.0031 \\
\hline 0.50 & 1.0286 & 100.140 & 0.0192 & 25 & 5.0842 & 0.4899 & 0.5022 & 0.0060 & 0.0061 & 0.0030 & 0.0031 \\
\hline 1.00 & 1.0566 & 100.349 & 0.0196 & 25 & 10.1423 & 0.9565 & 0.9997 & 0.0058 & 0.0061 & 0.0030 & 0.0032 \\
\hline 1.50 & 1.0830 & 100.374 & 0.0194 & 25 & 15.1772 & 1.4025 & 1.4956 & 0.0057 & 0.0061 & 0.0029 & 0.0031 \\
\hline 2.00 & 1.1077 & 100.295 & 0.0195 & 25 & 20.2544 & 1.8358 & 1.9974 & 0.0056 & 0.0061 & 0.0029 & 0.0031 \\
\hline 2.50 & 1.1316 & 100.359 & 0.0194 & 25 & 25.3113 & 2.2524 & 2.4945 & 0.0055 & 0.0061 & 0.0028 & 0.0031 \\
\hline
\end{tabular}


Table 5.

$\underline{\text { Boron and Potassium Concentrations at } 25^{\circ} \mathrm{C}}$

\begin{tabular}{|c|c|c|c|c|}
\hline \multicolumn{2}{|c|}{ Electrolyte } & \multirow{2}{*}{$\begin{array}{c}\text { Equilibrium } \\
\mathrm{BF}_{4}^{-} \\
\text {molality }^{*}\end{array}$} & \multirow{2}{*}{$\begin{array}{c}\mathrm{BF}_{4}^{-} \\
\text {Hydrolysis } \\
\text { molality }\end{array}$} & \multirow{2}{*}{$\begin{array}{c}\mathrm{K} \\
\text { molality }\end{array}$} \\
\hline Species & molality & & & \\
\hline $\mathrm{NaNO}_{3}$ & 0.0000 & 0.0585 & 0.00047 & 0.0640 \\
\hline $\mathrm{NaNO}_{3}$ & 0.0503 & 0.0638 & 0.00051 & 0.0684 \\
\hline $\mathrm{NaNO}_{3}$ & 0.1003 & 0.0656 & 0.00052 & 0.0695 \\
\hline $\mathrm{NaNO}_{3}$ & 0.2007 & 0.0720 & 0.00052 & 0.0726 \\
\hline $\mathrm{NaNO}_{3}$ & 0.4976 & 0.0836 & 0.00066 & 0.0863 \\
\hline $\mathrm{NaNO}_{3}$ & 0.9963 & 0.0987 & 0.00074 & 0.105 \\
\hline $\mathrm{NaNO}_{3}$ & 1.4996 & 0.107 & 0.00079 & 0.116 \\
\hline $\mathrm{NaNO}_{3}$ & 2.0121 & 0.119 & 0.00084 & 0.125 \\
\hline $\mathrm{NaNO}_{3}$ & 2.5134 & 0.135 & 0.00093 & 0.144 \\
\hline $\mathrm{NaNO}_{3}$ & 3.0150 & 0.149 & 0.00101 & 0.152 \\
\hline $\mathrm{NaNO}_{3}$ & 3.5157 & 0.161 & 0.00104 & 0.166 \\
\hline $\mathrm{NaNO}_{3}$ & 4.0039 & 0.186 & 0.00115 & 0.180 \\
\hline $\mathrm{NaNO}_{3}$ & 4.9984 & 0.210 & 0.00124 & 0.212 \\
\hline $\mathrm{NaNO}_{3}$ & 5.9788 & 0.235 & 0.00113 & 0.231 \\
\hline $\mathrm{NaNO}_{3}$ & 7.0688 & 0.260 & 0.00141 & 0.265 \\
\hline $\mathrm{NaNO}_{3}$ & 8.0698 & 0.275 & 0.00146 & 0.283 \\
\hline $\mathrm{NaNO}_{3}$ & 9.0302 & 0.275 & 0.00147 & 0.279 \\
\hline $\mathrm{NaBF}_{4}$ & 0.0000 & 0.0585 & 0.00047 & 0.0640 \\
\hline $\mathrm{NaBF}_{4}$ & 0.0500 & 0.0897 & 0.00087 & 0.0405 \\
\hline $\mathrm{NaBF}_{4}$ & 0.1000 & 0.128 & 0.00136 & 0.0289 \\
\hline $\mathrm{NaBF}_{4}$ & 0.1993 & 0.217 & 0.00234 & 0.0199 \\
\hline $\mathrm{NaBF}_{4}$ & 0.2942 & 0.309 & 0.00302 & 0.0182 \\
\hline $\mathrm{NaBF}_{4}$ & 0.4015 & 0.416 & 0.00328 & 0.0179 \\
\hline $\mathrm{NaBF}_{4}$ & 0.4989 & 0.511 & 0.00349 & 0.0158 \\
\hline $\mathrm{NaBF}_{4}$ & 1.0032 & 1.010 & 0.00431 & 0.0115 \\
\hline $\mathrm{NaBF}_{4}$ & 1.4977 & 1.506 & 0.00494 & 0.0130 \\
\hline $\mathrm{NaBF}_{4}$ & 2.0037 & 2.011 & 0.00548 & 0.0128 \\
\hline $\mathrm{NaBF}_{4}$ & 2.5091 & 2.518 & 0.00602 & 0.0155 \\
\hline $\mathrm{KNO}_{3}$ & 0.0000 & 0.0585 & 0.00047 & 0.0640 \\
\hline $\mathrm{KNO}_{3}$ & 0.0490 & 0.0447 & 0.00024 & 0.0941 \\
\hline $\mathrm{KNO}_{3}$ & 0.1064 & 0.0385 & 0.00013 & 0.145 \\
\hline $\mathrm{KNO}_{3}$ & 0.2063 & 0.0295 & -0.00009 & 0.236 \\
\hline $\mathrm{KNO}_{3}$ & 0.3019 & 0.0282 & -0.00062 & 0.329 \\
\hline $\mathrm{KNO}_{3}$ & 0.4012 & 0.0300 & -0.00008 & 0.431 \\
\hline $\mathrm{KNO}_{3}$ & 0.5022 & 0.0268 & -0.00013 & 0.530 \\
\hline $\mathrm{KNO}_{3}$ & 0.9997 & 0.0236 & -0.00017 & 1.023 \\
\hline $\mathrm{KNO}_{3}$ & 1.4956 & 0.0271 & -0.00012 & 1.522 \\
\hline $\mathrm{KNO}_{3}$ & 1.9974 & 0.0250 & -0.00015 & 2.018 \\
\hline $\mathrm{KNO}_{3}$ & 2.4945 & 0.0233 & -0.00017 & 2.463 \\
\hline
\end{tabular}

* Measured or derived boron concentration corrected for added $\mathrm{H}_{3} \mathrm{BO}_{3}$ (subtracted) and after subtracting $\mathrm{BF}_{4}^{-}$hydrolysis, next column. 
Figure 2. Solubility Product of $\mathrm{KBF}_{4}$ in lonic Strength Adjuster Salts, $2^{\circ} \mathrm{C}$ Addition of Salts Increases Solubility

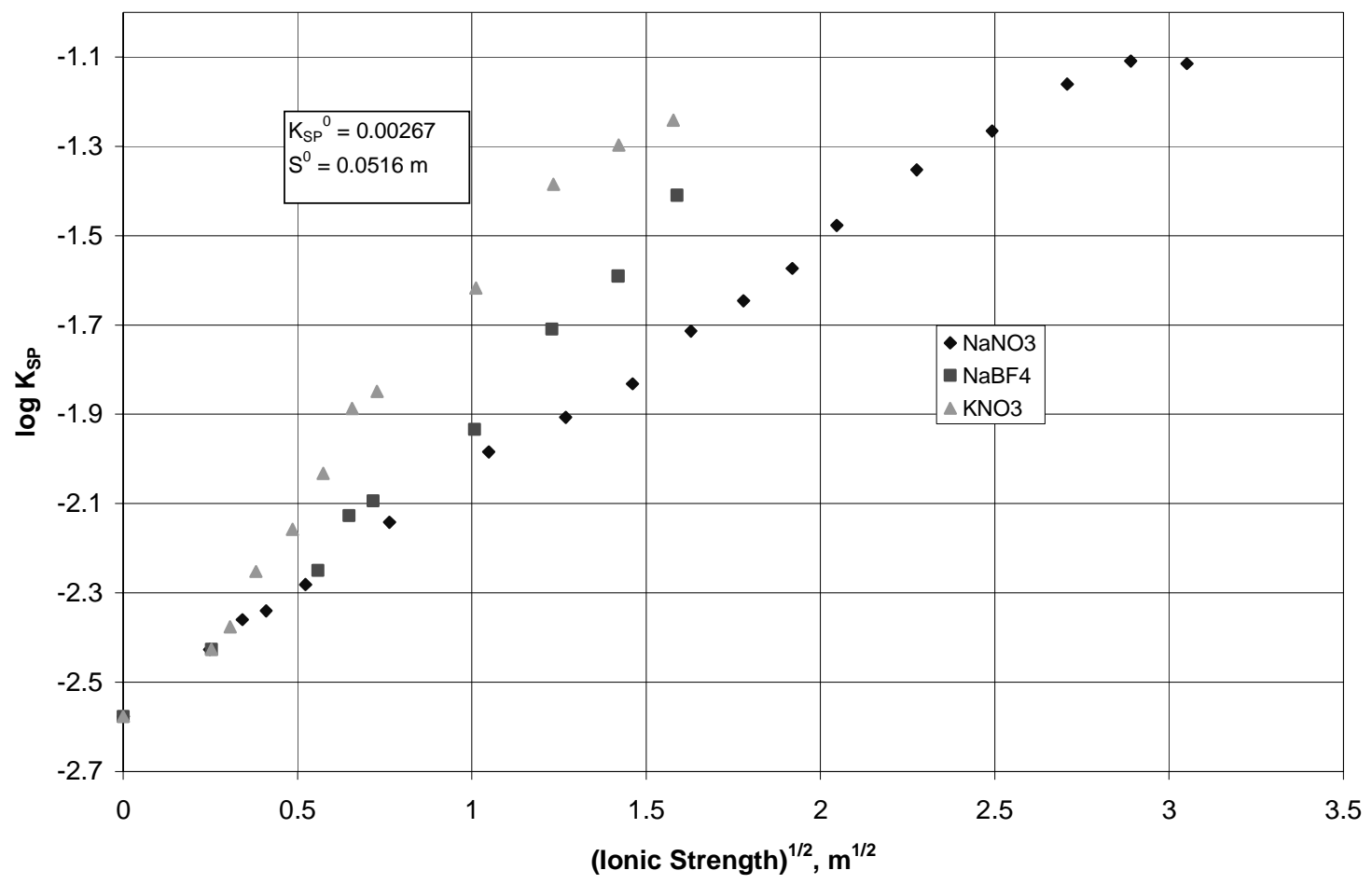

Figure 3. Activity Coefficient of $\mathrm{KBF}_{4}$ in lonic Strength Adjuster Salts, $25^{\circ} \mathrm{C}$

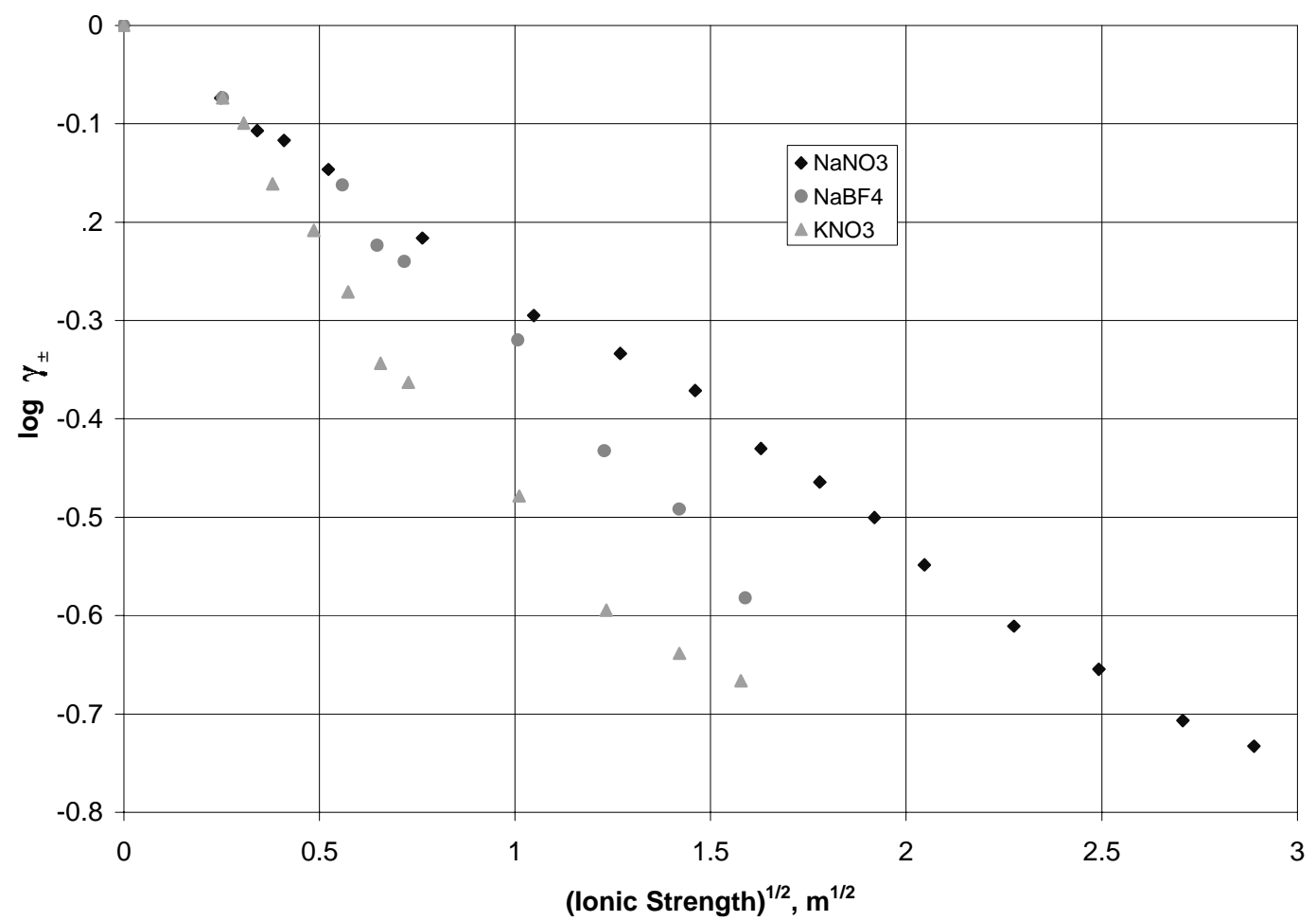


Table 6.

$\underline{\mathrm{KBF}}_{4} \underline{\text { Solubility Products and Activity Coefficients at } 25^{\circ} \mathrm{C}}$

\begin{tabular}{|c|c|c|c|c|}
\hline Electrolyte & $\mathrm{m}$ & $\mathrm{K}$ & $\begin{array}{c}\text { Ionic } \\
\text { Strength }\end{array}$ & $\begin{array}{c}\text { Mean Molal } \\
\text { Activity } \\
\text { Coefficient }\end{array}$ \\
\hline $\mathrm{NaNO}_{3}$ & 0.0000 & 0.00375 & 0.0640 & 0.844 \\
\hline $\mathrm{NaNO}_{3}$ & 0.0503 & 0.00436 & 0.1167 & 0.781 \\
\hline $\mathrm{NaNO}_{3}$ & 0.1003 & 0.00456 & 0.1681 & 0.764 \\
\hline $\mathrm{NaNO}_{3}$ & 0.2007 & 0.00523 & 0.2733 & 0.714 \\
\hline $\mathrm{NaNO}_{3}$ & 0.4976 & 0.00721 & 0.5829 & 0.608 \\
\hline $\mathrm{NaNO}_{3}$ & 0.9963 & 0.0104 & 1.099 & 0.507 \\
\hline $\mathrm{NaNO}_{3}$ & 1.4996 & 0.0124 & 1.611 & 0.464 \\
\hline $\mathrm{NaNO}_{3}$ & 2.0121 & 0.0147 & 2.134 & 0.425 \\
\hline $\mathrm{NaNO}_{3}$ & 2.5134 & 0.0193 & 2.653 & 0.371 \\
\hline $\mathrm{NaNO}_{3}$ & 3.0150 & 0.0226 & 3.166 & 0.343 \\
\hline $\mathrm{NaNO}_{3}$ & 3.5157 & 0.0267 & 3.683 & 0.316 \\
\hline $\mathrm{NaNO}_{3}$ & 4.0039 & 0.0333 & 4.189 & 0.283 \\
\hline $\mathrm{NaNO}_{3}$ & 4.9984 & 0.0444 & 5.180 & 0.245 \\
\hline $\mathrm{NaNO}_{3}$ & 5.9788 & 0.0543 & 6.213 & 0.222 \\
\hline $\mathrm{NaNO}_{3}$ & 7.0688 & 0.0690 & 7.332 & 0.196 \\
\hline $\mathrm{NaNO}_{3}$ & 8.0698 & 0.0778 & 8.350 & 0.185 \\
\hline $\mathrm{NaNO}_{3}$ & 9.0302 & 0.0767 & 9.308 & 0.186 \\
\hline & & & & \\
\hline $\mathrm{NaBF}_{4}$ & 0.0000 & 0.00375 & 0.0640 & 0.844 \\
\hline $\mathrm{NaBF}_{4}$ & 0.0500 & 0.00363 & 0.0905 & 0.857 \\
\hline $\mathrm{NaBF}_{4}$ & 0.1000 & 0.00369 & 0.1289 & 0.850 \\
\hline $\mathrm{NaBF}_{4}$ & 0.1993 & 0.00432 & 0.2192 & 0.785 \\
\hline $\mathrm{NaBF}_{4}$ & 0.2942 & 0.00563 & 0.3124 & 0.688 \\
\hline $\mathrm{NaBF}_{4}$ & 0.4015 & 0.00746 & 0.4194 & 0.598 \\
\hline $\mathrm{NaBF}_{4}$ & 0.4989 & 0.00804 & 0.5147 & 0.575 \\
\hline $\mathrm{NaBF}_{4}$ & 1.0032 & 0.0116 & 1.015 & 0.479 \\
\hline $\mathrm{NaBF}_{4}$ & 1.4977 & 0.0195 & 1.511 & 0.369 \\
\hline $\mathrm{NaBF}_{4}$ & 2.0037 & 0.0256 & 2.016 & 0.322 \\
\hline $\mathrm{NaBF}_{4}$ & 2.5091 & 0.0389 & 2.524 & 0.262 \\
\hline $\mathrm{KNO}_{3}$ & 0.0000 & 0.00375 & 0.0640 & 0.844 \\
\hline $\mathrm{KNO}_{3}$ & 0.04900 & 0.00421 & 0.0942 & 0.796 \\
\hline $\mathrm{KNO}_{3}$ & 0.1064 & 0.00559 & 0.1451 & 0.690 \\
\hline $\mathrm{KNO}_{3}$ & 0.2063 & 0.00696 & 0.2357 & 0.619 \\
\hline $\mathrm{KNO}_{3}$ & 0.3019 & 0.00928 & 0.3291 & 0.536 \\
\hline $\mathrm{KNO}_{3}$ & 0.4012 & 0.0130 & 0.4312 & 0.453 \\
\hline $\mathrm{KNO}_{3}$ & 0.5022 & 0.0142 & 0.5293 & 0.433 \\
\hline & 0.9997 & 0.0241 & 1.023 & 0.332 \\
\hline 1.4956 & 0.0412 & 1.522 & 0.254 \\
\hline & 2.4945 & 0.0504 & 2.020 & 0.230 \\
\hline & & \multicolumn{2}{|c|}{} \\
\hline
\end{tabular}


Table 7. $\underline{\mathrm{KBF}}_{4} \underline{\text { Gravimetric Hydrolysis Experiments }}$

\begin{tabular}{|c|c|c|c|c|c|c|c|c|}
\hline & $\mathrm{H}_{2} \mathrm{O}$ & $\mathrm{H}_{3} \mathrm{BO}_{3}$ & $\mathrm{HF}$ & $\mathrm{KBF}_{4}$ & $\mathrm{H}_{3} \mathrm{BO}_{3}$ & $\mathrm{HF}$ & Density & $\mathrm{KBF}_{4}$ \\
\hline Description & $\mathrm{g}$ & $\mathrm{g}$ & $\mu \mathrm{L}$ & $\mathrm{g}$ & $\mathrm{m}$ & $\mathrm{m}$ & $\mathrm{g} / \mathrm{mL}$ & $\mathrm{m}$ \\
\hline Pure $\mathrm{KBF}_{4}$ & 500.0 & 0 & 0 & 7 & 0 & 0 & 0.9979 & 0.0504 \\
\hline $\begin{array}{c}\mathrm{H}_{3} \mathrm{BO}_{3} \& \mathrm{HF} \\
\text { (same as in present study) }\end{array}$ & 500.0 & 0.628 & 102 & 7 & 0.00203 & 0.0051 & 1.0068 & 0.0517 \\
\hline $\begin{array}{l}\text { Excess } \mathrm{H}_{3} \mathrm{BO}_{3} \& \mathrm{HF} \\
\text { (to stop hydrolysis) }\end{array}$ & 500.0 & 0.631 & 144 & 7 & 0.00204 & 0.0072 & 1.0081 & 0.0529 \\
\hline
\end{tabular}

Table 8. $\mathrm{KBF}_{4} \underline{\text { Solubility Data Based on ICP Experimental Results, Molal Basis, } 25^{\circ} \mathrm{C}}$.

\begin{tabular}{|c|c|c|c|c|c|c|c|c|c|}
\hline \multirow{3}{*}{$\begin{array}{l}\text { Ionic } \\
\text { Strength } \\
\text { Adjuster }\end{array}$} & & & \multicolumn{7}{|c|}{$\begin{array}{l}\text { Values at Ionic Strength of KBF4 Saturation } \\
\text { No Added Ionic Strength Salt }\end{array}$} \\
\hline & \multicolumn{2}{|c|}{$\begin{array}{c}\text { ICP Data } \\
\text { Extrapolated to Zero } \\
\text { I, Davies Equation }\end{array}$} & \multicolumn{3}{|c|}{ Raw Saturation Data } & \multicolumn{2}{|c|}{$\begin{array}{c}\text { Calculated at I of } \\
\text { Saturation from } \\
\text { Davies Linear Fit } \\
\text { Equation }\end{array}$} & \multicolumn{2}{|c|}{$\begin{array}{l}\text { Literature Values } \\
\text { References } 13,14\end{array}$} \\
\hline & $\mathrm{K}_{\mathrm{SP}}^{0}$ & $S^{0}$ & I & $\mathrm{K}_{\mathrm{SP}}$ & $\mathrm{S}$ & $\mathrm{K}_{\mathrm{SP}}{ }^{*}$ & $\mathrm{~S}^{*}$ & $\mathrm{~K}_{\mathrm{SP}}{ }^{*}$ & $\mathrm{~S}^{*}$ \\
\hline $\mathrm{NaNO}_{3}$ & 0.00268 & 0.0518 & \multirow{5}{*}{0.0615} & \multirow{5}{*}{0.00375} & \multirow{5}{*}{0.0615} & 0.00382 & 0.0620 & & \\
\hline $\mathrm{NaBF}_{4}$ & 0.00268 & 0.0517 & & & & 0.00343 & 0.0588 & & \\
\hline $\mathrm{KNO}_{3}$ & 0.00289 & 0.0538 & & & & 0.00380 & 0.0619 & & \\
\hline \multirow[b]{2}{*}{ Average } & \multirow[b]{2}{*}{0.00275} & \multirow[b]{2}{*}{0.0524} & & & & \multirow[b]{2}{*}{0.00368} & \multirow[b]{2}{*}{0.0609} & 0.00183 & 0.043 \\
\hline & & & & & & & & 0.00380 & 0.062 \\
\hline
\end{tabular}

Corrected for hydrolysis. To the two significant figures provided in the literature, there is no difference between with and without the hydrolysis correction.

Table 9. Summary Comparisons at Ionic Strength of Saturation, No Added Salt, $25^{\circ} \mathrm{C}$.

\begin{tabular}{|l|l|c|c|}
\hline \multicolumn{2}{|c|}{ Source of Results } & $\mathrm{K}_{\mathrm{SP}}$ & $\mathrm{S}$ \\
\hline \multirow{2}{*}{ Present Study } & ICP Data & 0.0037 & 0.061 \\
\cline { 2 - 4 } & Gravimetric Data & 0.0026 & 0.052 \\
\hline \multirow{2}{*}{ Literature Values } & Stolba (1872) & 0.043 \\
\cline { 2 - 4 } & $\begin{array}{l}\text { DeBoer \& Van Liempt } \\
(1927)^{14}\end{array}$ & 0.0018 & 0.062 \\
\hline
\end{tabular}

\section{Discussion}

In general, electrolyte solution reactions generate additional species that substantially increase the number of possible binary and ternary parameters. The findings of the experimental program provide a foundation of basic chemical data (solubility products and activity coefficients) applicable to the prevention of $\mathrm{KBF}_{4}$ precipitation, with key binary and ternary interaction parameters considered. An important observation is that increasing the ionic strength increases the solubility of $\mathrm{KBF}_{4}$ substantially, which means that plant solutions will be able to tolerate higher concentrations of boron than would be estimated in the absence of activity coefficients. 
Application of the INEEL speciation program to solutions characteristic of SRS dissolvers requires evaluation of activity coefficients via the Pitzer correlation parameters. To obtain the Pitzer parameters in the multielectrolyte systems, the procedure developed by Pitzer and $\mathrm{Kim}^{15}$ was followed. They developed a linear graphical procedure derived from empirical correlations for evaluation of the ternary system ion interaction parameters $\theta_{i j}$ and $\Psi_{\mathrm{ijk}}$

$$
\Delta \ln \gamma_{\mathrm{MX}}\left(\frac{v}{2 v_{M} m_{N}}\right)=\theta_{M N}+\frac{1}{2}\left(m_{X}+m_{M}\left|\frac{z_{M}}{z_{X}}\right|\right) \Psi_{M N X}
$$

where, $\mathrm{m}_{\mathrm{N}}$ is the molality of the cation of the ionic strength adjuster salt. The term $\Delta \ln \gamma_{\mathrm{MX}}$ is the difference between the experimental value of $\ln \gamma_{\mathrm{MX}}$ with the appropriate single-salt parameters values for the pure single-electrolyte terms, but with $\theta_{M N}=$ $\Psi_{M N X}=0$ in the multielectrolyte activity coefficient equation. Pitzer's approach was followed: the left side of equation (9) was plotted against the coefficient of $\Psi$ on the right side to obtain a linear plot with intercept $\theta$ and slope $\Psi$. This simple approach avoided the need to solve the non-linear activity coefficient equations using multiple regression.

However, in the application of this approach down to small concentrations of the ionic strength adjuster salt $\left(\mathrm{m}_{\mathrm{N}}\right.$ in equation (9)), a non-linear plot resulted due to the left side approaching infinity as $m_{N}$ approached zero. This is evident in Figure 4 for the $\mathrm{NaNO}_{3}$ system using the literature value for $\theta_{\mathrm{K}-\mathrm{Na}}$ of -0.012 . This problem was first identified by Khoo $^{16}$ and subsequently by Kim and Frederick. ${ }^{17}$ Accordingly, the data processing approach of non-linear multiple regression is appropriate and needed. This effort is in progress. Upon its completion, a journal article will be prepared of the results.

The $\mathrm{KBF}_{4}$ solubility data (based on ICP results) compare well with previously reported values (DeBoer and Van Liempt ${ }^{14}$ ). The lower solubility determined via gravimetric methods is not understood. Consequently, there is a degree of uncertainty in the $\mathrm{K}_{\mathrm{SP}}^{0}$ and $\mathrm{K}_{\mathrm{SP}}$ at saturation, no added salt based on the ICP and gravimetric comparisons. Nevertheless, the activity coefficients are valid because of the use of a self consistent set of ICP data from which the used $\mathrm{K}_{\mathrm{SP}}^{0}$ value was extrapolated. It is noted that the gravimetric measurements with added $\mathrm{H}_{3} \mathrm{BO}_{3}$ and $\mathrm{HF}$ could not discern the extent of hydrolysis.

The INEEL model was previously adapted to SRS plant dissolver solutions to support the 1997 Sand, Slag, and Crucible campaign and the Mark 42 Fuel Tube campaign. This was due to a high concentration of fluoride ions in boric acid/nitric acid solutions that led to the formation of a white solid (see Table 10). The white solids were collected from these flow sheet simulations and were identified as $\mathrm{KBF}_{4}$.

The conditions that shift the equilibria towards precipitation are qualitatively understood in terms of Le Chatelier's principle by considering the following equations: 


$$
\begin{gathered}
\mathrm{H}_{3} \mathrm{BO}_{3}(\mathrm{aq})+3 \mathrm{H}^{+}(\mathrm{aq})+4 \mathrm{~F}^{-}(\mathrm{aq})=\mathrm{BF}_{4}^{-}(\mathrm{aq})+3 \mathrm{H}_{2} \mathrm{O}(\mathrm{l}) \\
\mathrm{K}^{+}(\mathrm{aq})+\mathrm{BF}_{4}^{-}(\mathrm{aq})=\mathrm{KBF}_{4}(\mathrm{~s}) \\
\mathrm{K}^{+}(\mathrm{aq})+\mathrm{H}_{3} \mathrm{BO}_{3}(\mathrm{aq})+4 \mathrm{~F}^{-}(\mathrm{aq})+3 \mathrm{H}^{+}(\mathrm{aq})=\mathrm{KBF}_{4}(\mathrm{~s})+3 \mathrm{H}_{2} \mathrm{O}(\mathrm{l})
\end{gathered}
$$

Test Case 37 is just at saturation and Case 38 is over-saturated. These cases were modeled with the INEEL speciation program with the results shown in Table 11.

The model properly predicts precipitation of $\mathrm{KBF}_{4}$ at $0.60-\mathrm{M}$ fluoride but slightly overpredicts solution stability at $0.50-\mathrm{M}$ fluoride. This observation may be due to a complex interaction of activity coefficients of the ions in solution and the effect of $\mathrm{HNO}_{3}$ on activity of HF. To optimize model development, it is necessary to determine the activity coefficients of $\mathrm{HF}$ in $\mathrm{HNO}_{3}$ and apply them in combination with calculated activity coefficients for the ionic species in solution. This can be done following completion of the regression fitting of the Pitzer ion interaction parameters (see Appendix). As it stands, the model can predict the KF concentration stability limit to within about $12 \%$. This is based on the $41 \%$ of saturation predicted at $0.50 \mathrm{M} \mathrm{KF}$ and correct prediction at $0.60 \mathrm{M} \mathrm{KF}\left[(1-0.41)^{*}(0.60-0.50) / 0.50\right]=0.12$. This precision is sufficient for plant process control with safety factors.

Figure 4. Pitzer-Kim Linear Eq. 9 Plot for $\mathrm{KBF}_{4}$ in $\mathrm{NaNO}_{3}$ Ionic Strength Adjuster Showing Non-Linearity Effect.

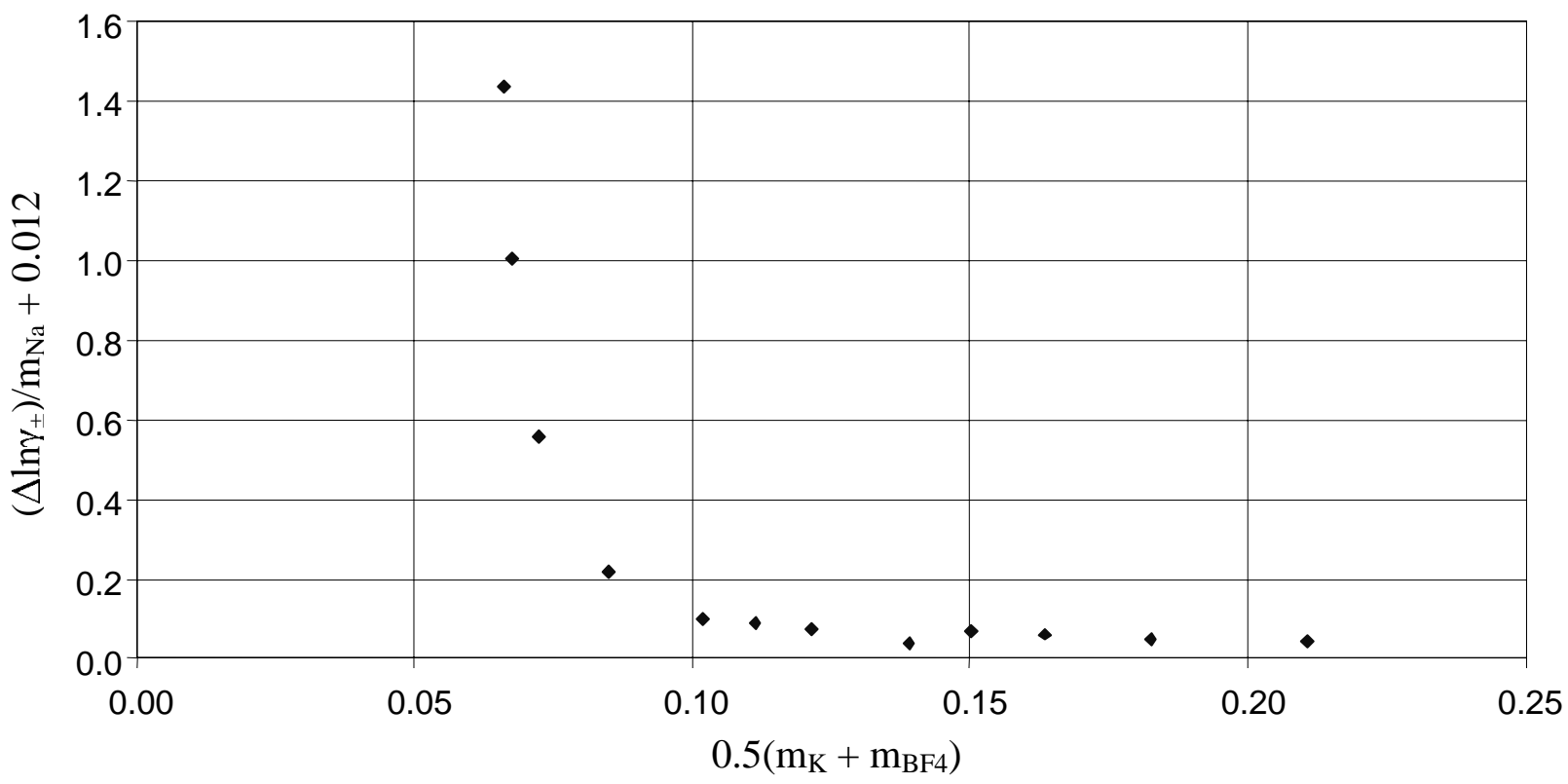


Table 10. $\underline{K B F}_{4} \underline{\text { Saturation Experiments in SRS Plant Solutions }}$

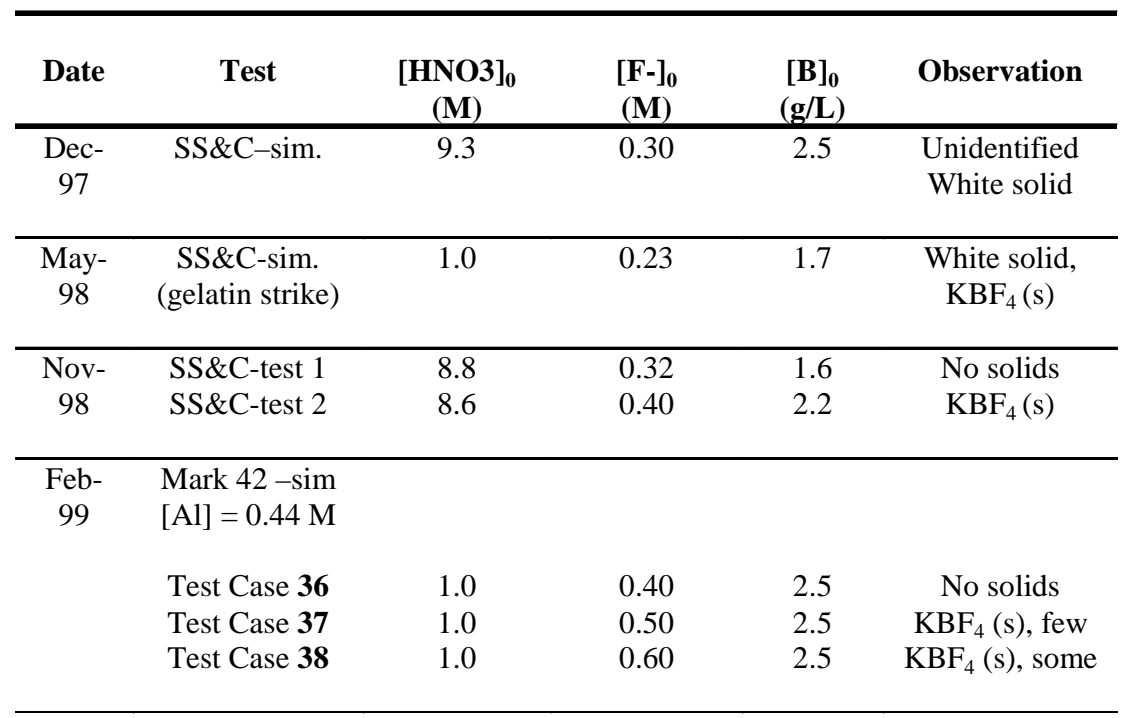

Table 11. Modeling Results for $\mathrm{KBF}_{4}$ Experiments, $20^{\circ} \mathrm{C}$

\begin{tabular}{|c|c|c|c|c|l|l|}
\hline $\begin{array}{c}\text { Test } \\
\text { Case }\end{array}$ & $\begin{array}{c}{\left[\mathrm{HNO}_{3}\right]_{0}} \\
\mathrm{M}\end{array}$ & $\begin{array}{c}{[\mathrm{KF}]_{0}} \\
\mathrm{M}\end{array}$ & $\begin{array}{c}{[\mathrm{B}]_{0}} \\
\mathrm{~g} / \mathrm{L}\end{array}$ & $\begin{array}{c}{[\mathrm{Al}]_{0}} \\
\mathrm{M}\end{array}$ & $\begin{array}{l}\text { Mark-42-sim } \\
\text { Observation }\end{array}$ & $\begin{array}{l}\text { Using INEEL program, } \\
\text { Calculated: }\end{array}$ \\
$\mathbf{3 7}$ & 1.0 & 0.50 & 2.5 & 0.44 & $\mathrm{KBF}_{4}(\mathrm{~s})$, few & $\begin{array}{l}{\left[\mathrm{BF}_{4}^{-}\right]=41.2 \% \text { of saturation }} \\
\text { (i.e. no precipitation is predicted). }\end{array}$ \\
$\mathbf{3 8}$ & 1.0 & 0.60 & 2.5 & 0.44 & $\begin{array}{l}\text { Predicts saturated } \mathrm{KBF}_{4} . \\
\mathrm{KBF}_{4}(\mathrm{~s}), \\
\text { some }\end{array}$ & $\begin{array}{l}\text { Precipitate composition: } \\
1.9 \% \text { of } \mathrm{K}^{+} \\
7.6 \% \text { of } \mathrm{F}\left(4.9 \% \text { of } \mathrm{F} \text { as } \mathrm{KBF}_{4}\right)\end{array}$ \\
\hline
\end{tabular}

\section{Conclusions}

With the objective of preventing precipitation of undesirable solids during aggressive SRS dissolution processes of EM materials, new basic chemical data were determined leading to a better ability to predict and avoid solids production in aqueous process solutions at SRS. The basic chemical data includes solubility, activity coefficients, and solubility products of potassium tetrafluoroborate $\left(\mathrm{KBF}_{4}\right)$ at ionic strengths expected in process solutions. These data will enhance the capability of the INEEL program to calculate the equilibrium position for a given starting dissolver solution composition and the solution stability is determined. Solution compositions can be varied to determine the concentration limit at which precipitation will begin in a dissolver solution.

This effort to develop a predictive model of the stability of aqueous solutions of nuclear materials will enable the avoidance of concentrations that may cause salts to precipitate. Therefore, for the processing of off-normal material, the risk of producing unwanted solids that require processing to stop will be reduced. Processing delays result in higher operating costs. In addition, the improved model may reduce the work scope 
for future flowsheet development by identifying the concentration of dissolver solutions that avoid the precipitation of salts. As an initial impact, the improved INEEL model should reduce costs for the processing of difficult-to-dissolve residues from the Rocky Flats Environmental Technology Site by shortening the time it takes to determine dissolving solutions. As a long-term impact, this model should improve schedules to dissolve other off-normal nuclear materials and process aqueous solutions that are stored throughout the DOE complex.

\section{References}

1. Y. Liu and S. Watanasiri, Chem. Eng. Prog., 25-42, October 1999.

2. K. S. Pitzer, J. Phys. Chem., 77, 268 (1973).

3. K. S. Pitzer, "Ion Interaction Approach: Theory and Data Correlation," Chapter 3 in Activity Coefficients in Electrolyte Solutions, 2nd Edition, K. S. Pitzer, editor, CRC Press, Boca Raton, 1991.

4. C. C. Chen, H. I. Britt, J. F. Boston, and L. B. Evans, AIChE J. 28 (4), 588-596, (July 1982).

5. J. D. Christian, Dissolution of Sand, Slag, and Crucible Residues, Chemistry Modeling Considerations, Report Prepared for Westinghouse Savannah River Company, (January 5, 1998).

6. R. F. Platford, "Osmotic and activity coefficients of simple borates in aqueous solution at $25^{\circ}$ ", Canadian Journal of Chemistry, 47, 2271-2273 (1969).

7. S. L. Phillips, F. V. Hale, L. F. Silvester, and M. D. Siegel, Thermodynamic Tables for Nuclear Waste Isolation, Report NUREG/CR-4864/LBL-22860/SAND87-0323, Vol 1 (June 1988).

8. C. W. Davies, Ion Association (Butterworths, Washington, DC, 1962).

9. W. J. Hamer and Y. Wu, "Osmotic Coefficients and Mean Activity Coefficients of Uni-univalent Electrolytes in Water at 25C," J. Phys. Chem. Ref. Data, Vol. 1, No. 4, 1047-1099 (1972).

10. A. Roine, Outokumpo HSC Chemistry® for Windows, Chemical Reaction and Equilibrium Software with Extensive Thermochemical Database, Version 5.1, Outokumpo Research Oy Information Service, P O Box 60, FIN-28101 Pori, Finland; available from ESM Software, Hamilton, Ohio.

11. R. R. Hammer, A Determination of the Stability Constants of a Number of Metal Fluoride Complexes and Their Rates of Formation, Report ENICO-1004, August 1979. National Technical Information Service, Springfield, Virginia.

12. I. G. Ryss and B. B. Donskaya, Zh. Fiz. Khim., 33, 107 (1959).

13. Stolba, Chem. Zentr., 395 (1872).

14. De Boer, J. H. and Van Liempt, J. A. M., "Die Themische Dissoziation der Alkalibofluroide," Receuil des Travaux Chimiques des Pays-Bas, Vol. 46, No. 3, 124-132 (1927).

15. K. S. Pitzer and J. J. Kim, "Thermodynamics of Electrolytes. IV. Activity and Osmotic Coefficients for Mexed Electrolytes,” J. Amer. Chem. Soc., 96, 5701-5707 (1974).

16. H. H. Khoo, “Activity Coefficients in Mixed-electrolyte Solutions,” J. Chem. Soc., Faraday Trans. 1, 82, 1-12 (1986).

17. H-T. Kim and W. J. Frederick, Jr. "Evaluation of Pitzer Ion Interaction Parameters of Aqueous Mixed Electrolyte Solutions at $25^{\circ}$ C. 2. Ternary Mixing Parameters,” J. Chem. Eng. Data, 33, 278-283 (1988). 


\section{Appendix A}

\section{Hydrofluoric Acid Activity Coefficient}


This page is intentionally blank. 


\section{Impact of Hydrofluoric Acid Activity Coefficient}

Hydrofluoric acid (HF) is an important reactant in plant process solutions. HF participates in fluoride complexation reactions and metal fluoride precipitating processes. The fluoride complexation of metal ions affects solvent extraction of species such as uranium and plutonium. In the Idaho Nuclear Technology and Engineering Center (INTEC), processes for naval reactor Zircaloy fuels, the HF concentration was typically less than 0.1 molar in less than $1.8 \mathrm{M} \mathrm{HNO}_{3}$. Under those conditions, the activity coefficient of HF was near unity. Consequently, the metal fluoride complexation reaction constants could be incorporated into the INEEL chemical equilibrium software that calculated free HF concentration from the speciation of the system without accounting for the effect of $\mathrm{HNO}_{3}$ on $\mathrm{HF}$ activity coefficients.

In the SRS plant solutions, however, the $\mathrm{HNO}_{3}$ concentrations are significantly higher, up to 6 or 8 molar. Literature data indicate that at $\mathrm{HNO}_{3}$ concentrations above about 1.8 molar the activity coefficient of $0.1 \mathrm{M}$ HF increases dramatically. Two studies, while showing differing quantitative results, both demonstrate large effects. Vdovenko et al. ${ }^{1,2}$ determined that the activity coefficient (mole fraction basis) of $4 \mathrm{M} \mathrm{HF}$ varied from 1.1 to 4.0 as the $\mathrm{HNO}_{3}$ concentration increased from 0 to 6.6 molar. Brenneman and Donohoe $^{3}$ found that the vapor-phase HF content (over a series of solutions in which the HF concentration was held constant at $0.5 \mathrm{M}$ ) increased by a factor of nearly 25 as the $\mathrm{HNO}_{3}$ concentration was increased from 0 to $14 \mathrm{M}$. At $0.1 \mathrm{M} \mathrm{HF}$, the increase was not apparent until the $\mathrm{HNO}_{3}$ concentration exceeded about $1.7 \mathrm{M}$.

Preliminary experimental work showed that the amperometric response of a metal electrode ${ }^{4}$ selective to HF increases by a factor of 1.7 when the HF concentration is held constant at 0.1 molar and the $\mathrm{HNO}_{3}$ concentration is increased from 1.6 to 7.8 molar (Figure A-1). Blank experiments with $\mathrm{HNO}_{3}$ showed no electrode response to $\mathrm{HNO}_{3}$. Normally, amperometric measurements respond to concentrations rather than activity. However, the metal electrodes used for the HF measurements create an amperometric current density that is inversely determined by the thickness of an oxide film that is created by reaction of the metal with water and corroded to a steady-state thickness by $\mathrm{HF}^{4,5}$ The HF reaction rate with the oxide film is a function of the HF activity. Therefore, the electrode response is affected by HF activity. At an HF concentration of $0.05 \mathrm{M}$, the electrode response is unaffected by $\mathrm{HNO}_{3}$ concentrations up to $1.8 \mathrm{M},{ }^{6}$ but greater concentrations of either show an effect from $\mathrm{HNO}_{3}$.

The observation of the extreme effect of $\mathrm{HNO}_{3}$ on $\mathrm{HF}$ activity is in accord with the expected behavior for hydrogen-bonding solutes. ${ }^{3}$ As the nitric acid ties up water for solvation, the amount of water available to solvate the hydrofluoric acid drops, thereby increasing the effective $\mathrm{HF}$ concentration. ${ }^{7}$ Therefore, for the higher $\mathrm{HNO}_{3}$ concentrations in the SRS plant solutions, it would be beneficial to determine and incorporate $\mathrm{HF}$ activity coefficients as a function of $\mathrm{HNO}_{3}$ concentration into the INEEL speciation model. 
Figure A-1. Effect of $\mathrm{HNO}_{3}$ Concentration on Ti Electrode

Measurement of [HF] at $20.9^{\circ} \mathrm{C}$

Standardized $[\mathrm{HF}]=0.0927+/-0.0001 \mathrm{M}$

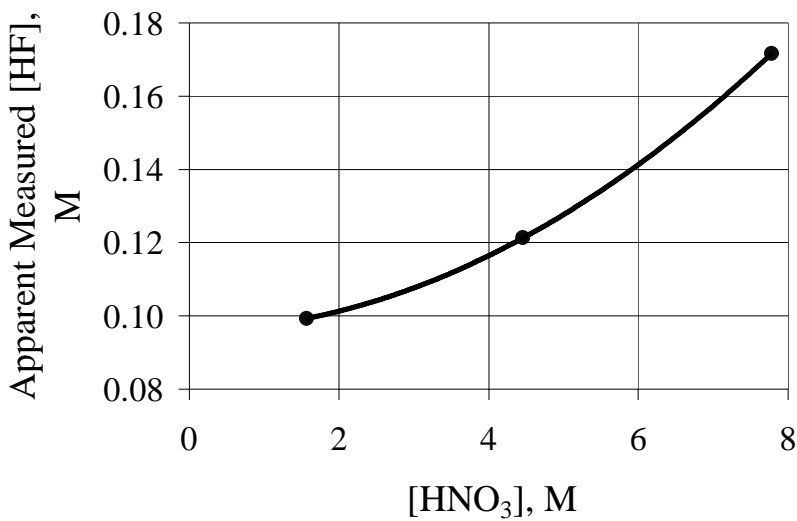

The activity of HF in the solutions is calculated from

$$
\mathrm{a}_{\mathrm{HF}}=\mathrm{p}_{\mathrm{HF}} / \mathrm{K}_{\mathrm{HF}}
$$

where $\mathrm{K}_{\mathrm{HF}}$ is the Henry's law constant, ${ }^{1} 0.46$ Torr $^{-1}$ for $\mathrm{HF}$ in water at $25^{\circ} \mathrm{C}$ and 1 atm total pressure. Then,

and

$$
\mathrm{f}_{\mathrm{HF}}=\mathrm{a}_{\mathrm{HF}} / \mathrm{m}_{\mathrm{HF}}
$$

$$
\gamma_{\mathrm{HF}}=\mathrm{a}_{\mathrm{HF}} / \mathrm{N}_{\mathrm{HF}}
$$

where $f_{H F}$ is the practical activity coefficient and $\gamma_{\mathrm{HF}}$ is the activity coefficient; $\mathrm{m}_{\mathrm{HF}}$ is molality and $\mathrm{N}_{\mathrm{HF}}$ is mole fraction of $\mathrm{HF}$ in solution.

\section{References for Appendix A}

1. V. M. Vdovenko, L. N. Lazarev, and E. V. Shirvinskii, "Study of the Thermodynamic Characteristics of the System $\mathrm{HF}-\mathrm{HNO}_{3}-\mathrm{H}_{2} \mathrm{O}$. I. Measurement of the Vapor Pressure of the Components of the Systems $\mathrm{HF}-\mathrm{H}_{2} \mathrm{O}$ and $\mathrm{HF}-\mathrm{HNO}_{3}-\mathrm{H}_{2} \mathrm{O}$," Soviet Radiochemistry, Vol. 7, No. 1, 45-47 (1965).

2. V. M. Vdovenko, L. N. Lazarev, E. V. Shirbinskii, and Yu. V. Gurikov, "Study of the Thermodynamic Characteristics of the System $\mathrm{HF}-\mathrm{HNO}_{3}-\mathrm{H}_{2} \mathrm{O}$. II. Calculation of the Activity of Components of the System $\mathrm{HF}-\mathrm{HNO}_{3}-\mathrm{H}_{2} \mathrm{O}$," Soviet Radiochemistry, Vol. 7 No. 2, 154-160 (1965).

3. K. R. Brenneman and R. J. Donohoe, "Monitoring Hydrofluoric Acid Activity by VaporPhase Infrared Spectroscopy," Appl. Spectroscopy, Vol. 48, No. 7, 808-812 (1994). 
4. J. D. Christian, J. A. Murphy, and D. B. Illum, "Metal Electrodes for Continuous Amperometric Measurement of Free Hydrofluoric Acid in Acidic Solutions Containing Complexing Ions," Talanta, 37, 651-654 (1990).

5. J. A. Murphy, Determination of the Zirconium Fluoride Stability Constants by Direct Measurement of Equilibrium Hydrofluoric Acid Using the Amperometric Response of Titanium and Hafnium Electrodes, WINCO-1098, May 1992; University of Idaho Masters Thesis.

6 J. D. Christian, Idaho Falls, Idaho, unpublished results.

7. I. N. Levine, Physical Chemistry (McGraw-Hill, New York 1978), p. 247. 